NASA Technical Memorandum 87118 AIAA-85-2014

\title{
Compatibility of Grain-Stabilized Platinum with Candidate Propellants for Resistojets
}

Margaret V. Whalen and Stanley P. Grisnik Lewis Research Center Cleveland, Ohio

\author{
Whenthe I G \\ DEC 20 Q085 \\ LANGLEY RESEARCH CENTE? \\ LIERARY, NASA \\ HAMPTON, VIRGINIA
}

Prepared for the

18th International Electric Propulsion Conference cosponsored by the AIAA, DGLR, and JSASS

Alexandria, Virginia, September 30-October 2, 1985 


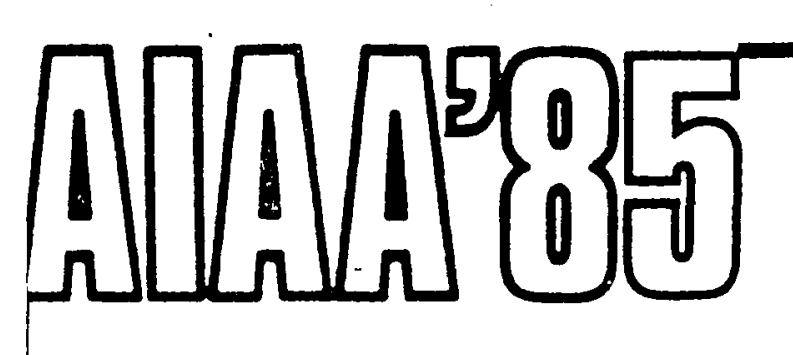

AIAA-85-2014

AIAA-85-2014

Compatibility of Grain-Stabilized Platinum with

Candidate Propellants for Resistojets

Margaret V. Whalen and Stanley P. Grisnik, NASA Lewis Research Center, Cleveland, $\mathrm{OH}$

\section{AIAA/DGLR/JSASS 18th International Electric Propulsion Conference September 30-October 2, 1985 Alexandria, Virginia}




\title{
COMPATIBILITY OF GRAIN-STABILIZED PLATINUM WITH CANDIDATE PROPELLANTS FOR RESISTOJETS
}

\author{
Margaret V. Whalen and Stanley P. Grisnik \\ National Aeronautics and Space Administration \\ Lewis Research Center \\ Cleveland, Ohio 44135
}

\section{Abstract}

Resistojets are candidates for Space Station auxiliary propulsion. Space Station resistojets should be characterized by both long life and multipropellant operations. These requirements are limited by available materials. In this study, grain stabilized platinum was examined for use as a resistojet thruster material. Use of platinum in other applications indicates it $c$ an be used at moderately high temperatures for extended periods of time. Past results indicate that grainstabilized platinum should be sufficiently inert in candidate propellant environments. Therefore, compatibility of platinum-yttria $\left(\mathrm{Pt} / \mathrm{Y}_{2} \mathrm{O}_{3}\right)$ and plat inum-zirconia $\left(\mathrm{Pt} / \mathrm{ZrO}_{2}\right)$ with carbon dioxide, methane, hydrogen and ammonia was examined.

A series of $1000 \mathrm{hr}$ tests in $\mathrm{CO}_{2}, \mathrm{H}_{2}$, and $\mathrm{NH}_{3}$ was conducted at $1400^{\circ} \mathrm{C}$ and a series of $1000 \mathrm{hr}$ tests in $\mathrm{CH}_{4}$ was conducted at about $500{ }^{\circ} \mathrm{C}$. Scanning electron microscopy, Auger electron spectroscopy and depth profiling analys is were then used to determine the effects of propellants on the material surface, to evaluate possible material contamination and to evaluate grain growth. The results indicated that there was carbon deposition on the surface of the $\mathrm{Pt} / \mathrm{Y}_{2} \mathrm{O}_{3}$ and $\mathrm{Pt} / \mathrm{ZrO}_{2}$ in both the $\mathrm{CO}_{2}$ and $\mathrm{CH}_{4}$ environments. In the $\mathrm{H}_{2}$ environment, the $\mathrm{Pt} / \mathrm{Y}_{2} \mathrm{O}_{3}$ and $\mathrm{Pt} / \mathrm{ZrO}_{2}$ specimen surfaces were roughened. After exposure to the $\mathrm{NH}_{3}$ environment, the $\mathrm{Pt} / \mathrm{Y}_{2} \mathrm{O}_{3}$ and $\mathrm{Pt} / \mathrm{ZrO}_{2}$ were roughened and pitted over the entire heated area with some pitted areas along the grain boundaries. SEM photos showed grain growth in crosssectional views of all the $\mathrm{Pt} / \mathrm{Y}_{2} \mathrm{O}_{3}$ samples and the $\mathrm{Pt} / \mathrm{ZrO}_{2}$ samples, except that tested in methane.

Mass loss measurements indicted that $\mathrm{Pt} / \mathrm{Y}_{2} \mathrm{O}_{3}$ and $\mathrm{Pt} / \mathrm{ZrO}_{2}$ would last in excess of $200000 \mathrm{hr}$ in each propellant environment. However, in $\mathrm{NH}_{3}$ both $\mathrm{Pt} / \mathrm{Y}_{2} \mathrm{O}_{3}$ and $\mathrm{Pt} / \mathrm{ZrO}_{2}$ were severely pitted, with voids up to 50 percent into the material. $\mathrm{Pt} / \mathrm{Y}_{2} \mathrm{O}_{3}$ and $\mathrm{Pt} / \mathrm{ZrO}_{2}$ are not recommended for high temperature service in $\mathrm{NH}_{3}$.

\section{Introduction}

Resistojet propulsion systems have the potential for reduced propellant requirements, reduction in propellant resupply servicing, and cost (because of availability of onboard fluids, such as $\mathrm{H}_{2} \mathrm{O}$ and $\mathrm{CO}_{2}$, for propulsion), long thruster life, low power consumption and low spacecraft contamination. These potential characteristics make resistojet propulsion systems attractive for Space Station auxiliary propulsion. The Space Station resistojet must meet the demanding requirements of long life and multipropellant operation. Meeting these requirements is limited by available materials and their properties. Therefore, the evaluation of resistojet materiais will have direct application to the development of multipropellant resistojets for Space Station auxiliary propulsion.
Two major considerations for candidate materials are the compatibility of these materials with potential Space Station propellants and the life limiting problem of grain growth. Grain growth can occur when a material is operated at high temperatures for extended periods of time, and can cause formation of voids, physical distortion and reduction in the stress-rupture performance of materials. Available grain-stabilized platinum materials appear to have characteristics that will enable them to meet the material requirements of Space Station resistojets.

Platinum and alloy-strengthened platinum were considered for biowaste resistojets during the Manned Orbital Research Laboratory program of the early 1970's. 1-3 Platinum was chosen for the biowaste application because of its excellent corrosion resistance, particularly for its high temperature oxidation resistance. 4 Pure platinum, aithough corrosion resistant, was found to lack adequate strength. Alloying the platinum with rhodium improved the material strength; however, compatibility problems arose because rhodium does not possess the corrosion resistance of plat inum. 5

Platinum-0.6 percent thoria was developed in the early 1970s as a grain-stabilized material for biowaste resistojets. This material was found to be compatible with $\mathrm{CO}_{2}$, but no other compatibility data were available. The platinum-thoria is no longer manufactured but the experience gained in producing it was used as a base for developing improved grain-stabilized platinum materials.

Short term compatibility tests with platinumyttria showed promising results. 6 Long-term tests are required, however, to expand the available data base for grain-stabilized platinum. Therefore, a study was conducted to determine the compatibility of grain-stabilized platinum with candidate Space Station resistojet propellants. A series of $1000 \mathrm{hr}$ tests with platinum-yttria and platinum-zirconia operated in carbon dioxide, methane, hydrogen and ammonia were completed. In each test, mass changes were measured and the projected life in each environment was determined. Also, the surface and cross section of the material was examined for contamination, deterioration and evidence of grain growth.

\section{Material Characteristics}

In selecting a candidate material for the Space Station resistojet application the major requirements considered were long life and the ability to withstand corrosion in a variety of propellant environments. Long life results in reduced thruster maintenance and replacement costs. Multipropellant capability enables operation with an oxidizing or reducing propel lant and thus provides the potential to use the variety of propellants that may be available onboard Space Station. Grain-stabilized platinum has the potential to meet these demanding requirements. 
Platinum is used in many applications because of its resistance to corrosion. The platinum melting point of $1769^{\circ} \mathrm{C}$ allows operation within the range of temperatures appropriate to space Station auxiliary propulsion requirements.

Two types of grain-stabilized platinum are currently available. One type is stabilized with yttria $\left(\mathrm{Y}_{2} \mathrm{O}_{3}\right)$ and the other with zirconia $\left(\mathrm{ZrO}_{2}\right)$. The addition of these stabilizing oxides to the platinum does not significantly change the physical properties or the room temperature mechanical properties of the base platinum material.7,8 However, in addition to improving creep resistance and imiting grain growth, the added oxides increase the high temperature strength of platinum. The platinum-yttria $\left(\mathrm{Pt} / \mathrm{Y}_{2} \mathrm{O}_{3}\right)$ and platinumzirconia $\left(\mathrm{Pt} / \mathrm{ZrO}_{2}\right)$ are produced by dispersing a fine oxide powder throughout the platinum metal. The process, known as dispersion strengthening, involved mechanical working and heat treatment. The resulting material has a coarse, elongated grain structure, as depicted in Fig. 1. The dispersant $\left(\mathrm{Y}_{2} \mathrm{O}_{3}\right.$ or $\left.\mathrm{ZrO}_{2}\right)$ limits grain growth and grain boundary sliding. The stabilizing oxide is approximately 0.13 percent by weight in the $\mathrm{Pt} / \mathrm{Y}_{2} \mathrm{O}_{3}$ and is approximately 0.1 percent by weight in the $\mathrm{Pt} / \mathrm{ZrO}_{2}$.

\section{Apparatus}

\section{Material Compatibility Tests}

Material compatibility tests were conducted in four test cells. Figure 2 is a schematic of the general arrangement of the test cells. The cell used for the $\mathrm{CO}_{2}$ tests was fabricated from quartz tubing whereas the tests with $\mathrm{CH}_{4}, \mathrm{H}_{2}$, and $\mathrm{NH}_{3}$ were conducted in stainless steel cells with a quartz viewing port. The $\mathrm{CO}_{2}$ test cell was approximately $7.62 \mathrm{~cm}$ diameter by about $20.32 \mathrm{~cm}$ length. The other test cells were $15.24 \mathrm{~cm}$ diameter by $30.48 \mathrm{~cm}$ length. The two test cell types used different seals. The quartz cell used silicon rubber 0-rings, while nickel or copper gaskets were used in the other cells. In the $\mathrm{NH}_{3}$ and $\mathrm{H}_{2}$ tests, flow control valves both upstream and downstream of the chamber regulated the flow. A roughing pump was used to purge the system and exiting gases were vented to the atmosphere. In the $\mathrm{CO}_{2}$ and $\mathrm{CH}_{4}$ tests, flow was also controiled by flow control valves, but exiting gases were drawn to a roughing pump.

The test samples were coiled platinum-yttria or platinum-zirconia tubes. The coils were fabricated from $0.203 \mathrm{~cm} 0 . d$. by $0.025 \mathrm{~cm}$ wall tubing, with approximately a $43.2 \mathrm{~cm}$ length of tubing required to make each coil. The $\mathrm{Pt} / \mathrm{Y}_{2} \mathrm{O}_{3}$ material required annealing at $1000{ }^{\circ} \mathrm{C}$ for $30 \mathrm{~min}$ to be coiled, this was not required to coil the $\mathrm{Pt} / \mathrm{ZrO}_{2}$. The tests used $100 \mathrm{~A}, 100 \mathrm{~V}$ dc power supplies. The power was applied to the coils through stainless steel support rods. Coil temperatures were measured using a two-color pyrometer in all but the tests with methane. In these tests a calibrated chromel-alumel thermocouple was used because the coil was tested at a temperature below the operating range of the pyrometer. The accuracy of the two-color pyrometer was 1 percent of full scale or $+14^{\circ} \mathrm{C}$. The thermocouple is accurate to about ${ }^{-}+25^{\circ} \mathrm{C}$, after correction, based on the method of cālibration.

\section{Procedure}

Each coiled tube was cleaned with a degreaser and ethyl alcohol and dried with high purity nitrogen before testing. The mass was measured using an analytical balance accurate to $0.1 \mathrm{mg}$. Gloves were used in handling samples before and after testing.

In all the $\mathrm{Pt} / \mathrm{Y}_{2} \mathrm{O}_{3}$ compatibility tests, the coils were maintained in a flowing gas environment. Prior to the test, the test cell was evacuated, purged with nitrogen and evacuated again. The cell was then brought to the $1.36 \times 10^{5} \mathrm{~Pa}$ (1020 torr) operating pressure by closing the gas outlet valve and introducing the gas into the chamber. The flow rate was set to about 100 standard $\mathrm{cm}^{3} / \mathrm{min}$. By opening the outlet valve and adjusting the flow control valves, the cell pressure could be maintained at the desired flow rate. The coils tested in $\mathrm{CO}_{2}, \mathrm{H}_{2}$, and $\mathrm{NH}_{3}$ were self-heated to approximately $1400{ }^{2} \mathrm{C}$ by an input of $40 \mathrm{~A}$, at $8 \mathrm{~V}$. The coils tests in $\mathrm{CH}_{4}$ were self-heated to about $500{ }^{\circ} \mathrm{C}$ by input of $20 \mathrm{~A}$ and $2 \mathrm{~V}$. This lower operating temperature was selected to avoid solid carbon formation from decomposing methane. The current, voltage, flow rate, coil temperature and cell pressure were recorded throughout each test. Each test was $1000 \mathrm{hr}$ or longer.

Material Evaluation

The tests reported herein were tests conducted to reinforce the favorable results obtained in $100 \mathrm{hr}$ tests of $\mathrm{Pt} / \mathrm{Y}_{2} \mathrm{O}_{3} 6$ and to obtain compatibility data on a similar material, $\mathrm{Pt} / \mathrm{ZrO}_{2}$. Several techniques were used to examine the compatibility of $\mathrm{Pt} / \mathrm{Y}_{2} \mathrm{O}_{3}$ and $\mathrm{Pt} / \mathrm{ZrO}_{2}$ with candidate propellants.

The mass change of the test samples was used as an indicator of the long life capability of the grain-stabilized platinum. The mass of each coil was taken before and after its exposure to the propellant evironment at temperatures typical of a resistojet heating element. An extrapolated coil life was postulated from the coil mass change. This life was based on a failure criterion of 10 percent gross specimen mass loss. Mass measurements are accurate to $+0.1 \mathrm{mg}$, which implies a maximum error of $0 . \overline{2} \mathrm{mg}$. Because most mass changes were greater than $1.0 \mathrm{mg}$, the maximum errors were less than \pm 10 percent.

The material surface reaction and the effect of propellant on the material grain stabilization were evaluated by several techniques. A scanning electron microscope was used to photograph coil surfaces and cross sections before and after testing. A comparison of the material surface structure and relative grain size before and after testing was made to determine if any reaction between the propellant and the material had occurred. Auger electron spectroscopy (AES) was employed to determine the constituents on the material surface. This technique can detect elements within approximately $50 \mathrm{~A}$ of the sample surface that are greater than approximately 0.5 atom percent. The Auger technique can be combined with ion beam sputtering to generate profiles of composition as a function of depth. In these analyses, depth profiles were generated by sputtering with $1 \mathrm{keV} \mathrm{Ar}^{+}$, at a sputter rate of 
$10 \mathrm{~A} / \mathrm{min}$. The goal of AES and depth profiling was to determine if the reaction of the propellant and the material extended below the material surface.

The Auger electron spectroscopy technique enables elemental characterization of the surface of the $\mathrm{Pt} / \mathrm{Y}_{2} \mathrm{O}_{3}$ and $\mathrm{Pt} / \mathrm{ZrO}$. The data acquired does not take matrix effects into account because a pure sample is not available for comparison. Ignoring these effects can lead to errors in determining compositions. The results are, therefore, somewhat qualitative and are best used for relative comparison of the material.

\section{Results and Discussion}

The results that follow include data on both platinum-yttria and platinum-zirconia. The objective of these studies was to determine the compatibility of grain-stabilized platinums with candidate resistojet propellants, not to compare the materials.

\section{Mass Changes}

A summary of the compatibility experiments is presented in Table I. The mass of each coil sample was taken before and after $1000 \mathrm{hr}$ of exposure to flowing gas environments, at typical resistojet heater temperatures.

The $\mathrm{Pt} / \mathrm{Y}_{2} \mathrm{O}_{3}$ sample tested in the $\mathrm{H}_{2}$ experienced a mass Toss of $0.0062 \mathrm{~g}$, which, based on the 10 percent mass loss life criterion, corresponds to an expected life in excess of $200000 \mathrm{hr}$. The $\mathrm{Pt} / \mathrm{Y}_{2} \mathrm{O}_{3} \mathrm{COil}$ in $\mathrm{NH}_{3}$ also has an expected life in excess of $200000 \mathrm{hr}$, however; as will be discussed later, the material integrity is not maintained. The best result was obtained for the sample tested in $\mathrm{CH}_{4}$, which had an expected life in excess of $1500000 \mathrm{hr}$. It should be noted that this sample was operated at a temperature of about $500{ }^{\circ} \mathrm{C}$ to minimize methane decomposition and resulting carbon deposition. Therefore, the lower operating temperature may have led to the higher life value. The extrapolated 1 ife of the $\mathrm{Pt} / \mathrm{Y}_{2} \mathrm{O}_{3}$ coil tested in $\mathrm{CO}_{2}$ was in excess of $300000 \mathrm{hr}$.

The $\mathrm{Pt} / \mathrm{ZrO} \mathrm{O}_{2}$ coils were tested under the same conditions as the $\mathrm{Pt} / \mathrm{Y}_{2} \mathrm{O}_{3}$ coil tests. The minimum extrapolated life calculated for $\mathrm{Pt} / \mathrm{ZrO}_{2}$ in $\mathrm{CO}_{2}, \mathrm{CH}_{4}, \mathrm{H}_{2}$ or $\mathrm{NH}_{3}$ was also approximately $200000 \mathrm{hr}$. The sample tested in $\mathrm{CH}_{4}$ experienced no measurable mass change; however, there appeared to be a coating over the surface of the sample. The $\mathrm{Pt} / \mathrm{ZrO}_{2}$ sample tested in $\mathrm{NH}_{3}$ experienced the greatest mass loss, $0.0066 \mathrm{~g}$, which corresponded to an expected life of $200000 \mathrm{hr}$. The coils tested in $\mathrm{H}_{2}$ and $\mathrm{CO}_{2}$ had extrapolated lives of 400000 and $800000 \mathrm{hr}$, respectively.

These mass changes and life calculations do not take into account redeposition of the base metal or deposit of contaminants, such as carbon on the surface of the material. Calculations made based on the surface analysis discussed in the next section indicate that generally surface contaminants total an order of magnitude less than obtained mass losses, and are, therefore, considered negligible. After testing, the facilities were clean with no evidence of metal deposition. These factors indicate that the lifetime values based on mass loss are fairly realistic. Additionally, these lifetimes are at least an order of magnitude higher than is expected to be required of Space Station resistojets.

\section{Surface Analysis Results}

After testing, the material was examined for deterioration, surface contamination and grain growth. Figure 3 shows a typical untested platinum-yttria surface. Figures 4 to 7 show the surface of the platinum-yttria samples after $1000 \mathrm{hr}$ exposure to $\mathrm{CO}_{2}, \mathrm{CH}_{4}, \mathrm{H}_{2}, \mathrm{NH}_{3}$, respectively. Each photograph shows the material at $200 \mathrm{X}$. The surface of the sample tested in $\mathrm{CO}_{2}$ shows some change and evidence of a deposit. After exposure to $\mathrm{CH}_{4}$, the sample surface appeared unchanged. The surface of the sample tested in $\mathrm{H}_{2}$ looks roughened. The sample tested in $\mathrm{NH}_{3}$ showed the most severe change, with the surface roughened and pitted over the entire exposed area. Figure 8 shows the surface of the sample tested in ammonia at $1000 \mathrm{X}$, revealing large grains at the surface. The other samples showed no evidence of grain growth at the surface even at higher magnifications.

Figure 9 shows the cross section of an annealed $\mathrm{Pt} / \mathrm{Y}_{2} \mathrm{O}_{3}$ tube. Figures 10 to 13 show cross-sectional views of the samples tested in $\mathrm{CO}_{2}, \mathrm{CH}_{4}, \mathrm{H}_{2}$ and $\mathrm{NH}_{3}$ respectively. The grain growth appears to be slight in all cases, with grain size approximately equal in samples operated at different temperatures. The grain growth is suspected to have occurred during the initial annealing, after which the grain size appears to be stable. The cross-sectional photo of the sample tested in ammonia also shows the extent to which the pitting on the surface goes into the material. Ammonia appears to deteriorate platinum, therefore, platinum may not be acceptable for this application.

Figure 14 is a photograph of a platinumzirconia surface prior to testing. Figures 15 to 18 are the $\mathrm{Pt} / \mathrm{ZrO}_{2}$ samples after testing in $\mathrm{CO}_{2}$, $\mathrm{CH}_{4}, \mathrm{H}_{2}$ and $\mathrm{NH}_{3}$. The $\mathrm{CO}_{2}$ sample has a deposit dotted over the surface. The sample exposed to $\mathrm{CH}_{4}$ appeared similar to the untested sample; however, there was a coating over the material surface. In visually examining this sample, the coating had the appearance of being thicker at the center coils of the sample, which was the highest temperature region of the sample. The $\mathrm{H}_{2}$ sample appears roughened. The $\mathrm{Pt} / \mathrm{ZrO}_{2}$ sample tested in $\mathrm{NH}_{3}$ was rough and pitted. Photos at higher magnification showed evidence of grain growth on the surface only in the $\mathrm{NH}_{3}$ sample, as seen in Fig. 19.

A cross section of an untested $\mathrm{Pt} / \mathrm{ZrO}_{2}$ sample is shown in $\mathrm{Fig}$. 20. The sample tested in $\mathrm{CH}_{4}$ showed no significant change in grain size, as seen in Fig. 21 . Figures 22 to 24 show grain growth in the $\mathrm{CO}_{2}, \mathrm{H}_{2}$ and $\mathrm{NH}_{3}$ samples which were tested at $1400^{\circ} \mathrm{C}$. The cross section of the sample tested in $\mathrm{NH}_{3}$ also showed that the pitting that appeared in the surface photos extended well into the material. In this case, as well as in the case of the sample of $\mathrm{Pt} / \mathrm{Y}_{2} \mathrm{O}_{3}$ tested in $\mathrm{NH}_{3}$, further evaluation is necessary to determine what is occurring at the ammonia-platinum interface. 
The $\mathrm{Pt} / \mathrm{ZrO}_{2}$ samples were not annealed prior to testing. Annealing may have resulted in grain growth similar to the $\mathrm{Pt} / \mathrm{Y}_{2} \mathrm{O}_{3}$ results. These factors should emphasize that no comparison should be made between the material grain growth.

Each material was also examined using Auger electron spectroscopy and AES combined with depth profiling. These techniques give the approximate atom percent of the constituents at the material surface and at desired depths below the surface. In these studies the components at the material surface were determined and compared to the composition of a sample at a depth of $200 \mathrm{~A}$. The 200 A depth was chosen for comparison because contamination levels in most samples tended to become constant at about this depth.

Table II shows the atom percentages of the major constituents present on the $\mathrm{Pt} / \mathrm{Y}_{2} \mathrm{O}_{3}$ samples. In all cases the contaminants, $\mathrm{C}, \mathrm{H}_{2}, \mathrm{~N}_{2}$ and $\mathrm{O}_{2}$ dropped to low levels from the surface to the $200 \mathrm{~A}$ depth. The $\mathrm{H}_{2}$ and $\mathrm{NH}_{3}$ surface contaminant levels were much lower than the $\mathrm{CO}_{2}$ and $\mathrm{CH}_{4}$ surface contaminant levels. These two samples also did not appear to be coated in the SEM photographs. Much of the composition at the surface is believed to be contamination from handling and exposure to air. The surface composition of the materials tested in $\mathrm{CO}_{2}$ and $\mathrm{CH}_{4}$ indicated higher levels of carbon and also indicted the presence of silicon. At the operating temperature of the $\mathrm{CH}_{4}$ test, about $500{ }^{\circ} \mathrm{C}$, slow decomposition of methane may be occurring, which may explain the higher surface carbon levels on that sample. In both the $\mathrm{CO}_{2}$ and $\mathrm{CH}_{4}$ tests, mechanical roughing pumps were used in the purging and shutdown procedures.

These pumps used hydrocarbon based oils, which may be a source of free carbon. Also, test cells for the $\mathrm{Pt} / \mathrm{Y}_{2} \mathrm{O}_{3}$ tests in $\mathrm{CO}_{2}$ and $\mathrm{CH}_{4}$ used silicon o-ring seals. These seals are rated for high temperature service; however, over extended periods of operation the seals may start to deteriorate. This deterioration is believed to be the primary source of silicon found on the $\mathrm{Pt} / \mathrm{Y}_{2} \mathrm{O}_{3}$ surfaces.

Table III shows the atom percentages of the major constituents on the $\mathrm{Pt} / \mathrm{ZrO}_{2}$ both at the surfaces and at $200 \AA$ depths. The surface compositions are again highly contaminated with carbon, oxygen, nitrogen as well as silicon on the sample tested in $\mathrm{CO}_{2}$. The levels drop quickly as the material is depth profiled in all cases except the sample tested in methane. Handling and exposure may account for much of these surface contaminates. The carbon levels remained high at the $200 \mathrm{~A}$ depth for the sample tested in $\mathrm{CH}_{4}$. Further depth profiling indicated these carbon levels remained 50 percent to a depth of about $500 \AA$. The presence of hydrocarbon oil from the pumps and/or the slow decomposition of the test gases may again be the main sources of carbon in the $\mathrm{CH}_{4}$ tests as well as the $\mathrm{CO}_{2}$ test. Further study is recommended to better assess the relatively high carbon levels below the surface of the sample tested in $\mathrm{CH}_{4}$. The 0-ring seals are the likely source of sificon on the $\mathrm{CO}_{2}$ sample. Depth profiling further into the material showed that the silicon level does not start dropping off significantly until a depth of approximately $1500 \mathrm{~A}$. The effect of the silicon on the material was not investigated in this study; however, past studies ${ }^{9}$ indicated that pure platinum may become embrittled because of silicon contamination.
The trends in the Auger and depth profiling for both the $\mathrm{Pt} / \mathrm{Y}_{2} \mathrm{O}_{3}$ and the $\mathrm{Pt} / \mathrm{ZrO}_{2}$ indicate that the samples have surface layers of contamination which are $200 \mathrm{~A}$. These results indicate that any reactions between the grain-stabilized platinums and the propellants examined tend to occur and be limited to the material surface. Further depth profiling shows contamination levels drop to that of the background; this leads to the conclusion that most of the material-gas interaction is confined to the surface.

\section{Conclusions}

A study of the compatibility of grainstabilized platinum with potential Space Station resistojet propellants has been completed. This study consisted of a series of $1000 \mathrm{hr}$ tests with platinum-yttria and platinum-zirconia exposed to flowing gas environments of $\mathrm{CO}_{2}, \mathrm{H}_{2}$, and $\mathrm{NH}_{3}$ at $1400{ }^{\circ} \mathrm{C}$ and $\mathrm{CH}_{4}$ at $500{ }^{\circ} \mathrm{C}$. Sample mass changes, material surface changes and grain growth were used as factors in determining material compatibility.

The samples tested were representative of resistojet heating elements. The life estimates, extrapolated from mass loss measurements and using 10 percent mass loss as the failure criterion, indicated that both $\mathrm{Pt} / \mathrm{Y}_{2} \mathrm{O}_{3}$ and $\mathrm{Pt} / \mathrm{ZrO}_{2}$ samples will withstand. a minimum of $200000 \mathrm{hr}$ in the $\mathrm{CO}_{2}, \mathrm{CH}_{4}, \mathrm{H}_{2}$ or $\mathrm{NH}_{3}$ environments. Slight grain growth occurred in each $\mathrm{Pt} / \mathrm{Y}_{2} \mathrm{O}_{3}$ sample. The grains are expected to be stable as the grain growth is suspected to have occurred primary during annealing. The $\mathrm{Pt} / \mathrm{ZrO}_{2}$ samples operated at $1400{ }^{\circ} \mathrm{C}$ in $\mathrm{CO}_{2}, \mathrm{H}_{2}$, and $\mathrm{NH}_{3}$ experienced grain growth. The sample tested in $\mathrm{CH}_{4}$ did not show a significant change in grain size. More detailed studies are needed to determine exactly how much grain growth occurs in $\mathrm{Pt} / \mathrm{Y}_{2} \mathrm{O}_{3}$ and $\mathrm{Pt} / \mathrm{ZrO} \mathrm{O}_{2}$, and the effects of grain growth on the operation of a resistojet. Surface analysis conducted to identify the contaminants that may have deposited on sample surfaces indicated carbon, oxygen and nitrogen evident on all samples, and on the $\mathrm{Pt} / \mathrm{Y}_{2} \mathrm{O}_{3}$ samples in $\mathrm{CO}_{2}$ and $\mathrm{CH}_{4}$, a small amount of silicon. The seals used in the $\mathrm{CO}_{2}$ and $\mathrm{CH}_{4}$ test cells were the suspected source of silicon. Pump oils, handling and exposure to air are suspected major sources of the other contaminants. Depth profiling of the sample indicated that the surface layers of contamination are very thin $(\leq 200 \mathrm{~A})$.

The results indicate the $\mathrm{Pt} / \mathrm{Y}_{2} \mathrm{O}_{3}$ and $\mathrm{Pt} / \mathrm{ZrO}_{2}$ are compatible with $\mathrm{CO}_{2}, \mathrm{CH}_{4}$ and $\mathrm{H}_{2}$ under the test conditions presented here. The interaction between both $\mathrm{Pt} / \mathrm{Y}_{2} \mathrm{O}_{3}$ and $\mathrm{Pt} / \mathrm{ZrO}_{2}$ with ammonia should be studied further.

Based on this investigation it is believed that $\mathrm{Pt} / \mathrm{Y}_{2} \mathrm{O}_{3}$ and $\mathrm{Pt} / \mathrm{ZrO}_{2}$ will be acceptable for use in both reducing and oxidizing propellant environments, but is not recommended for high temperature operation in ammonia. These materials appear to be likely candidates for Space Station resistojets using $\mathrm{CO}_{2}, \mathrm{CH}_{4}$, and $\mathrm{H}_{2}$ as propellants.

\section{References}

1. Halbach, C.R., "10 mlb Biowaste Resistojet Performance," AIAA Paper 71-687, June 1971. 
2. Halbach, C.R. and Yoshida, R.Y., "Development of a Biowaste Resistojet, " Journal of Spacecraft Rockets, Vol. 8, No. 3, Mar. 1971, pp. 273-277.

3. Albert, H.J.; and Hill, J.S., "Development of a Platinum-Thorium-0xide Alloy for Resistojet Thruster Use," Engelhard Minerals and Chemicals Corp., Newark, NJ, July 1971. (NASA CR-111959)

4. Knight, J.R., and Taylor, B., "Production and Properties of Grain-Stabilized Platinum and Plat inum Alloys," Powder Metallurgy, No. 10, Dec. 1962, pp. 108-118.

5. VanLandingham, E.E., and Willis, S.P.,

"Integrated Environmental Control/Life

Support Resistojet Systems," AIAA

Paper 70-1130, Sept. 1970.
6. Whalen, M.V., Grisnik, S.P., and Sovey, J.S., "Compatibility Experiments of Facilities, Materials and Propellants for Electrothermal Thrusters," NASA TM-86956, 1985.

7. Selman, G.L., Day, J.G., and Bourne, A.A., "Dispersion Strengthened Platinum," Platinum Metals Review, Vol. 18, No. 2, Apr. 1974, pp. 46-57.

8. Stanley, R.G., and Wilson, F.G., "ODS [0xide Dispersion Strengthened] Platinum - a Unnique High Temperature Material for the Most Demanding Applications," Metal Powder Report, Vol. 37, No. 4, Apr. 1982, pp. 175-176, 178.

9. Bennett, H.E., "The Care of Platinum Thermocouples," Platinum Metals Review, Vol. 2, No. 4, Oct. 1958, pp. 120-123.

TABLE I. - SUMMARY OF GRAIN STABILIZIED

PLATINUM EXPERIMENTS

\begin{tabular}{|c|c|c|c|c|}
\hline Propellant & $\begin{array}{c}\text { Coiled } \\
\text { heater } \\
\text { temp- } \\
\text { ature, } \\
{ }^{\circ} \mathrm{C}\end{array}$ & $\begin{array}{c}\text { Heater } \\
\text { initial } \\
\text { mass, } \\
\mathrm{g}\end{array}$ & $\begin{array}{c}\text { Coiled } \\
\text { heater } \\
\text { mass } \\
\text { loss, } \\
\mathrm{g}\end{array}$ & $\begin{array}{c}\text { Extrapolated } \\
\text { life, } \\
\mathrm{hr}\end{array}$ \\
\hline \multicolumn{6}{|c|}{ Platinum - Yttria } \\
\hline $\mathrm{CO}_{2}$ & 1400 & 9.0194 & 0.0030 & 300000 \\
$\mathrm{CH}_{4}$ & 500 & 12.6384 & .0008 & 1500000 \\
$\mathrm{H}_{2}$ & 1400 & 12.6589 & .0062 & 200000 \\
$\mathrm{NH}_{3}$ & 1400 & 12.5982 & .0055 & 200000 \\
\hline \multicolumn{6}{|c|}{ Platinum - Zirconia } \\
\hline $\mathrm{CO}_{2}$ & 1400 & 13.1955 & 0.0016 & 800000 \\
$\mathrm{CH}_{4}$ & 500 & 11.6969 & $.0000 \mathrm{C}$ & $>1000000$ \\
$\mathrm{H}_{3}$ & 1400 & 13.2093 & .0031 & 400000 \\
$\mathrm{NH}_{3}$ & 1400 & 13.0632 & .0066 & 200000 \\
\hline
\end{tabular}

aAfter $1000 \mathrm{hr}$ operation.

bTime to 10 percent mass loss.

$\mathrm{c}_{<} 0.0001 \mathrm{~g}$, accuracy of balance.

TABLE II. - APPROXIMATE ATOM PERCENT COMPOSITION OF $P t / Y_{2} 0_{3}$ AT THE SURFACE AND AT A 200 A DEPTH

\begin{tabular}{|l|c|c|c|c|c|c|c|c|c|c|}
\hline \multirow{2}{*}{ Propellant } & \multicolumn{2}{|c|}{ Platinum } & \multicolumn{2}{c|}{ Carbon } & \multicolumn{2}{c|}{ 0xygen } & \multicolumn{2}{c|}{ Silicon } & \multicolumn{2}{c|}{ Nitrogen } \\
\cline { 2 - 10 } & Surface & $200 \mathrm{~A}$ & Surface & $200 \mathrm{~A}$ & Surface & $200 \mathrm{~A}$ & Surface & $200 \mathrm{~A}$ & Surface & $200 \mathrm{~A}$ \\
\hline Carbon dioxide & 18.6 & 78 & 64.8 & 8.0 & 5.0 & 8.9 & 2.4 & 4.4 & 1.6 & $<1.0$ \\
Methane & 5.9 & 88 & 81.2 & 9.0 & 5.5 & 1.2 & 2.6 & 1.8 & 3.1 \\
Hydrogen & 43.9 & 98 & 42.1 & 1.7 & 4.9 & $<1.0$ & $<1.0$ & $<1.0$ & 2.8 & \\
Ammonia & 42.5 & 96.2 & 43.8 & 2.7 & 4.2 & $<1.0$ & $<1.0$ & $<1.0$ & 4.5 & \\
\hline
\end{tabular}


TABLE III. - APPROXIMATE ATOM PERCENT COMPOSITION OF Pt/Zr02 AT tHE SURFACE AND AT A 200 a DEPTH

\begin{tabular}{|l|c|c|c|c|c|c|c|c|c|c|}
\hline \multicolumn{1}{|c|}{ Propellant } & \multicolumn{2}{|c|}{ Platinum } & \multicolumn{2}{c|}{ Carbon } & \multicolumn{2}{c|}{ Oxygen } & \multicolumn{2}{c|}{ Silicon } & \multicolumn{2}{c|}{ Nitrogen } \\
\cline { 2 - 10 } & Surface & $200 \mathrm{~A}$ & Surface & $200 \mathrm{~A}$ & Surface & $200 \mathrm{~A}$ & Surface & $200 \mathrm{~A}$ & Surface & $200 \mathrm{~A}$ \\
\hline Carbon dioxide & 52.0 & 80 & 24.1 & 2.7 & 13.2 & 10 & 5.2 & 6.0 & 3.8 & $<1.0$ \\
& & & & & & & & & & \\
Methane & 5.6 & 21 & 85.1 & 77.0 & 5.9 & 1.8 & $<1.0$ & $<1.0$ & 1.2 & \\
Hydrogen & 39.2 & 96 & 50.3 & 3.3 & 3.2 & $<1.0$ & $<1.0$ & $<1.0$ & 3.9 & \\
Ammonia & 56.3 & 97 & 34.0 & 3.0 & 2.6 & $<1.0$ & $<1.0$ & $<1.0$ & 5.8 & \\
\hline
\end{tabular}




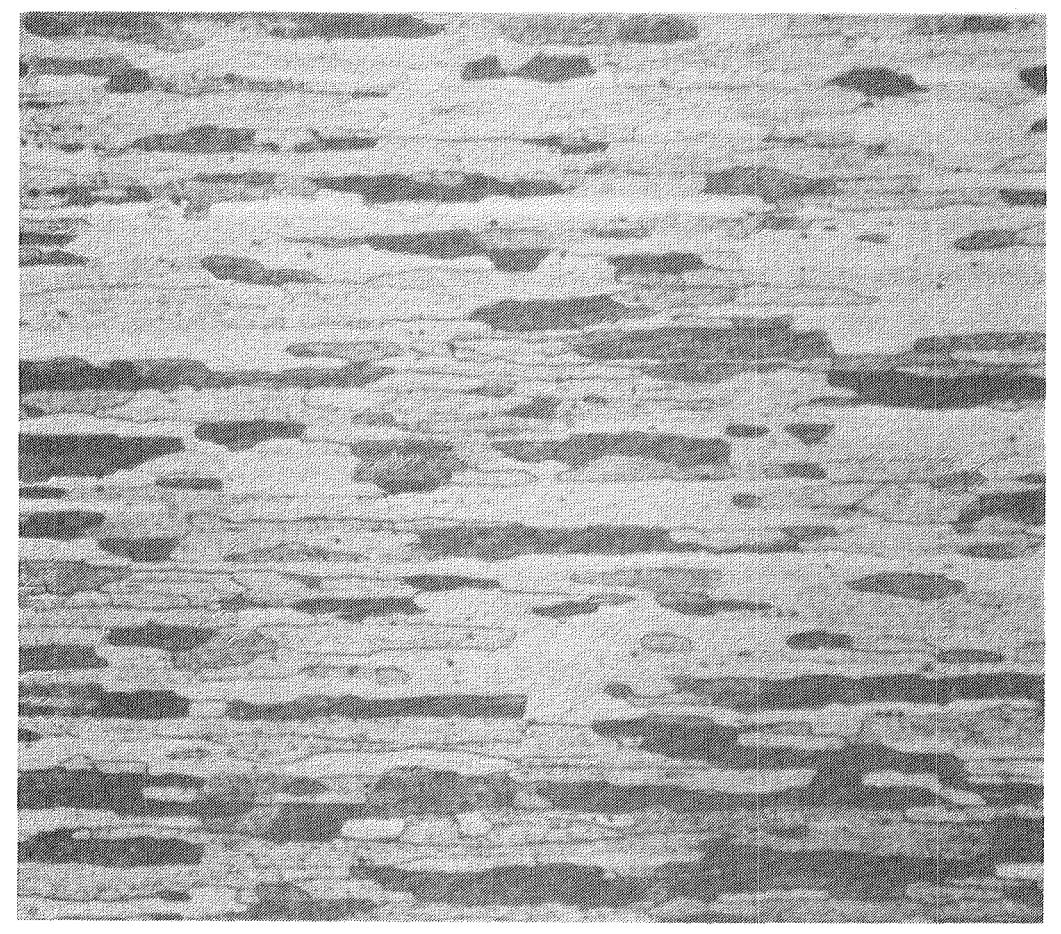

Figure 1. - Grain-stabilized platinum grain structure.

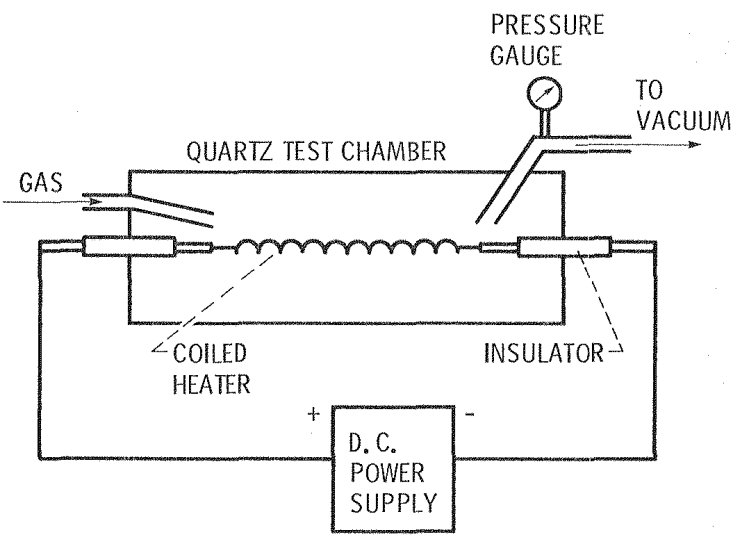

Figure 2. - Material experimental system. 


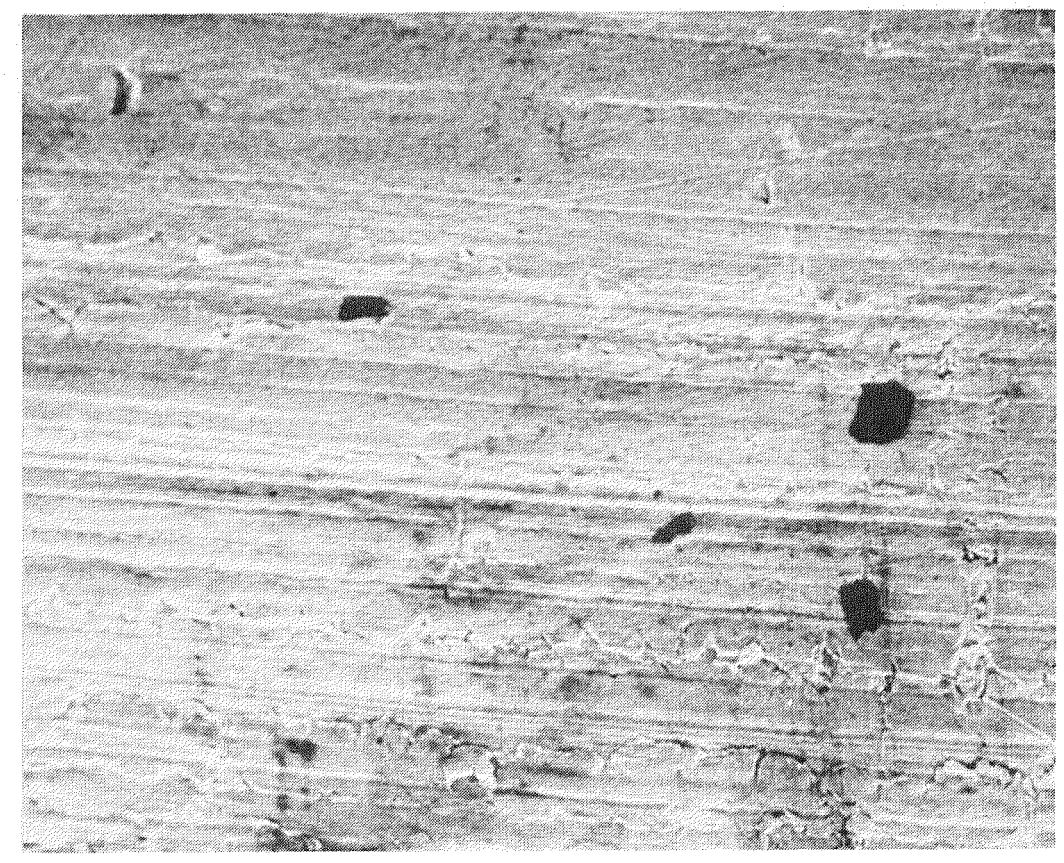

Figure 3. - Platinum-yttria surface prior to testing (200X).

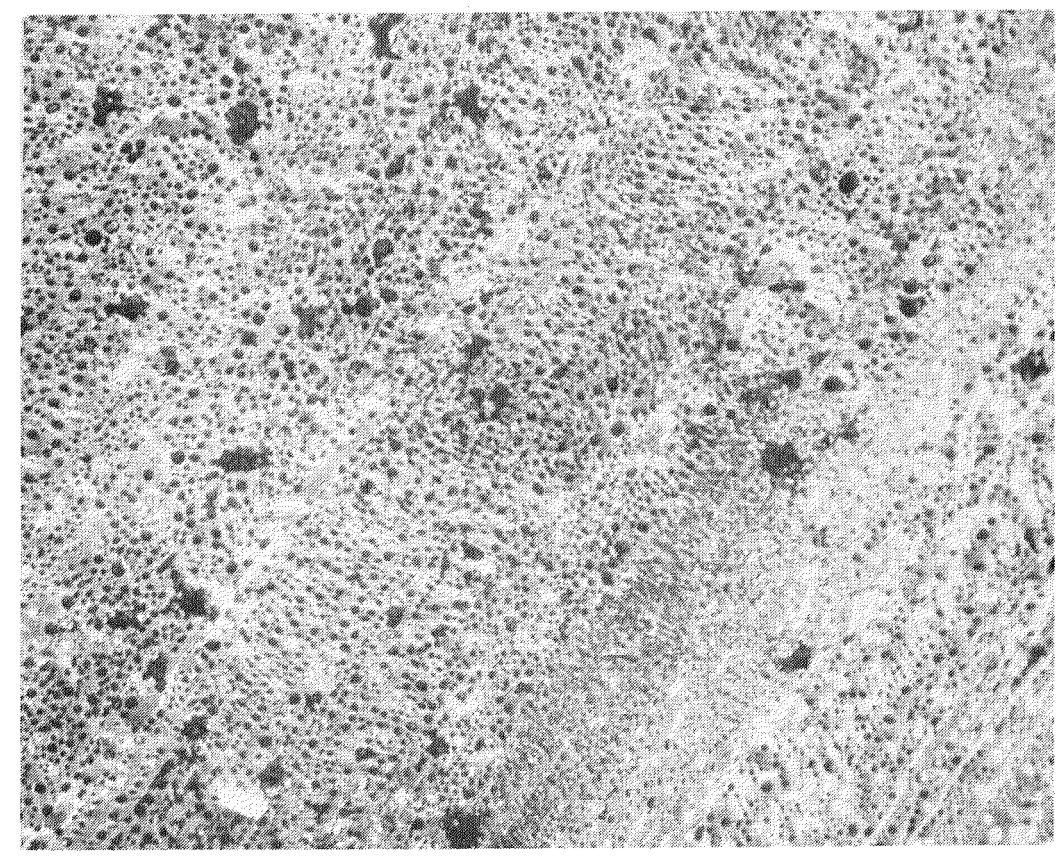

Figure 4. - Platinum-yttria surface after $1000 \mathrm{hr}$ at $1400{ }^{\circ} \mathrm{C}$ in $\mathrm{CO}_{2}(200 \mathrm{X})$. 


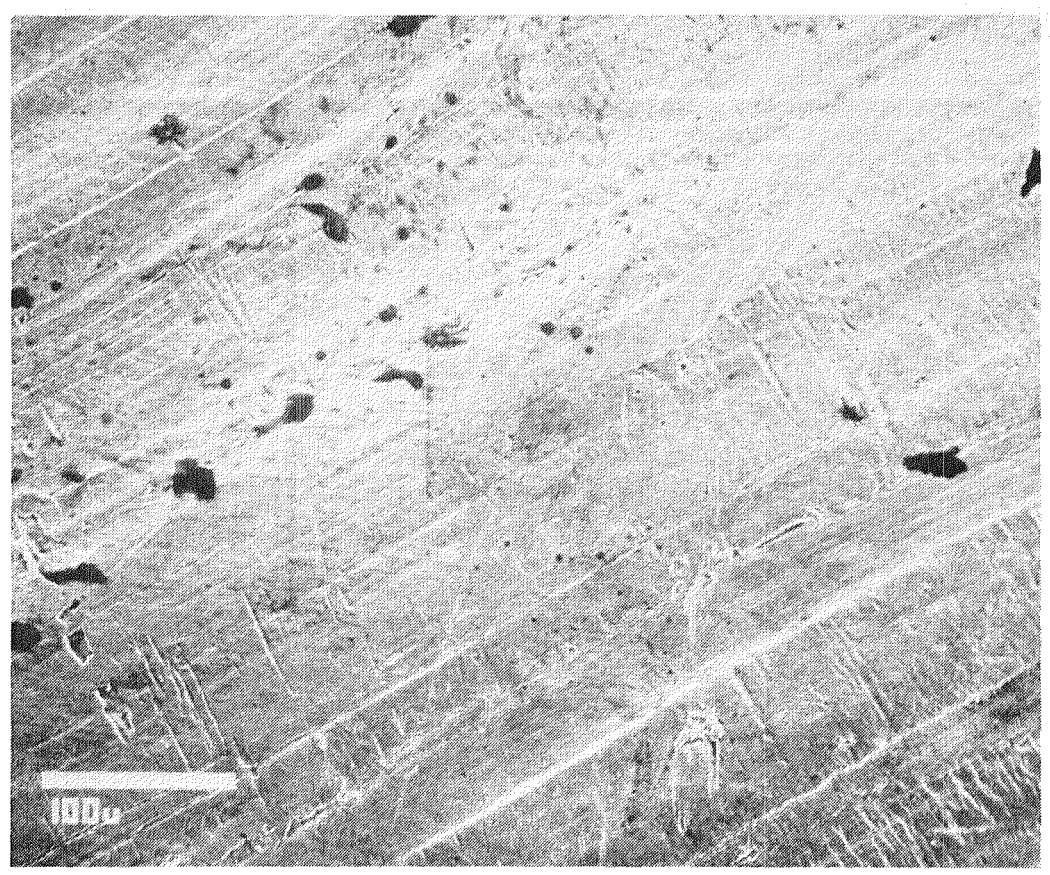

Figure 5. $-\mathrm{Pt} / \mathrm{Y}_{2} \mathrm{O}_{3}$ surface after $1000 \mathrm{hr}$ at $500{ }^{\circ} \mathrm{C}$ in $\mathrm{CH}_{4}(200 \mathrm{X})$.

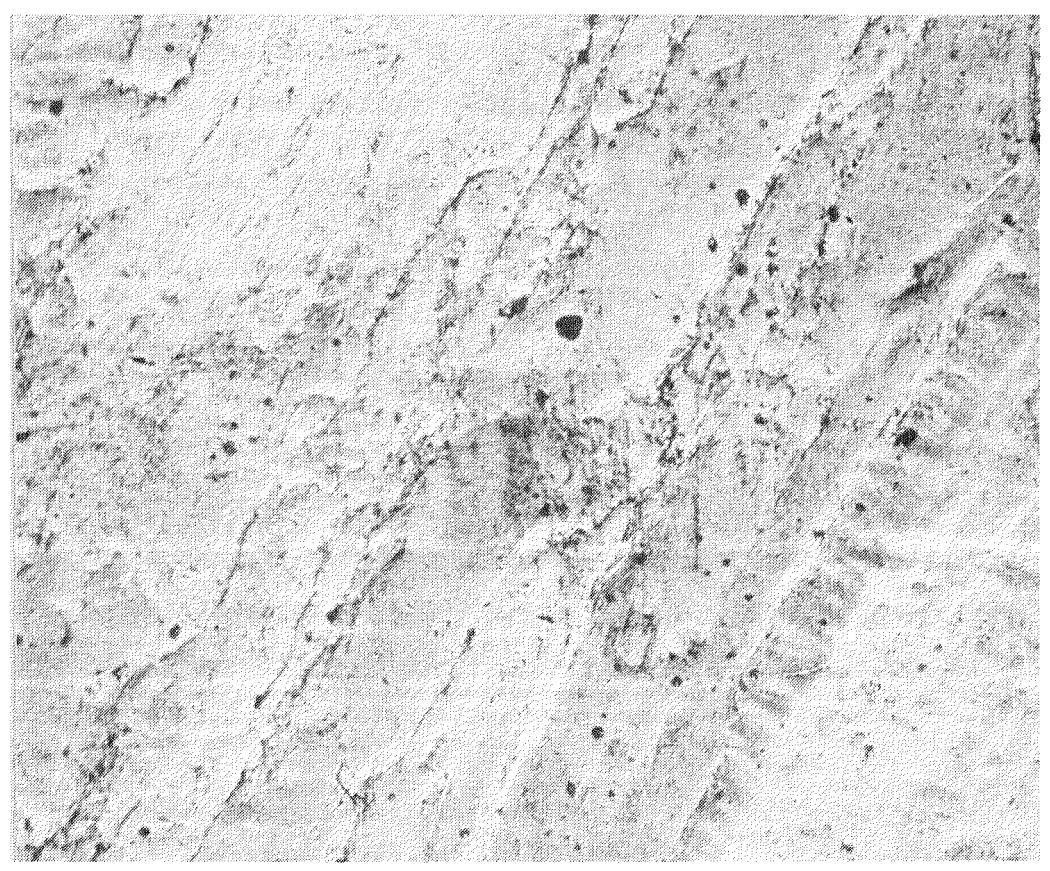

Figure 6. $-\mathrm{Pt} / \mathrm{Y}_{2} \mathrm{O}_{3}$ surface after $1000 \mathrm{hr}$ at $1400{ }^{\circ} \mathrm{C}$ in $\mathrm{H}_{2}(200 \mathrm{X})$. 


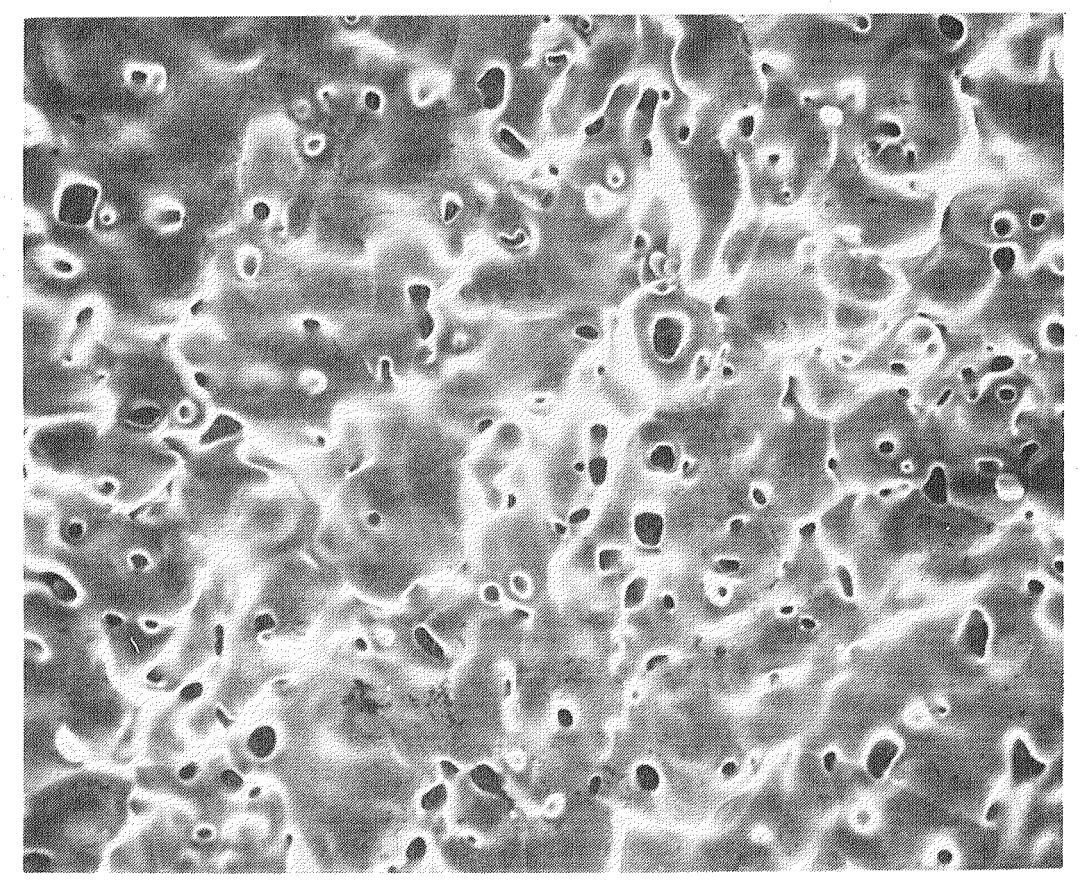

Figure 7. $-\mathrm{Pt} / \mathrm{Y}_{2} \mathrm{O}_{3}$ surface after $1000 \mathrm{hr}$ at $1400{ }^{\circ} \mathrm{C}$ in $\mathrm{NH}_{3}(200 \mathrm{X})$.

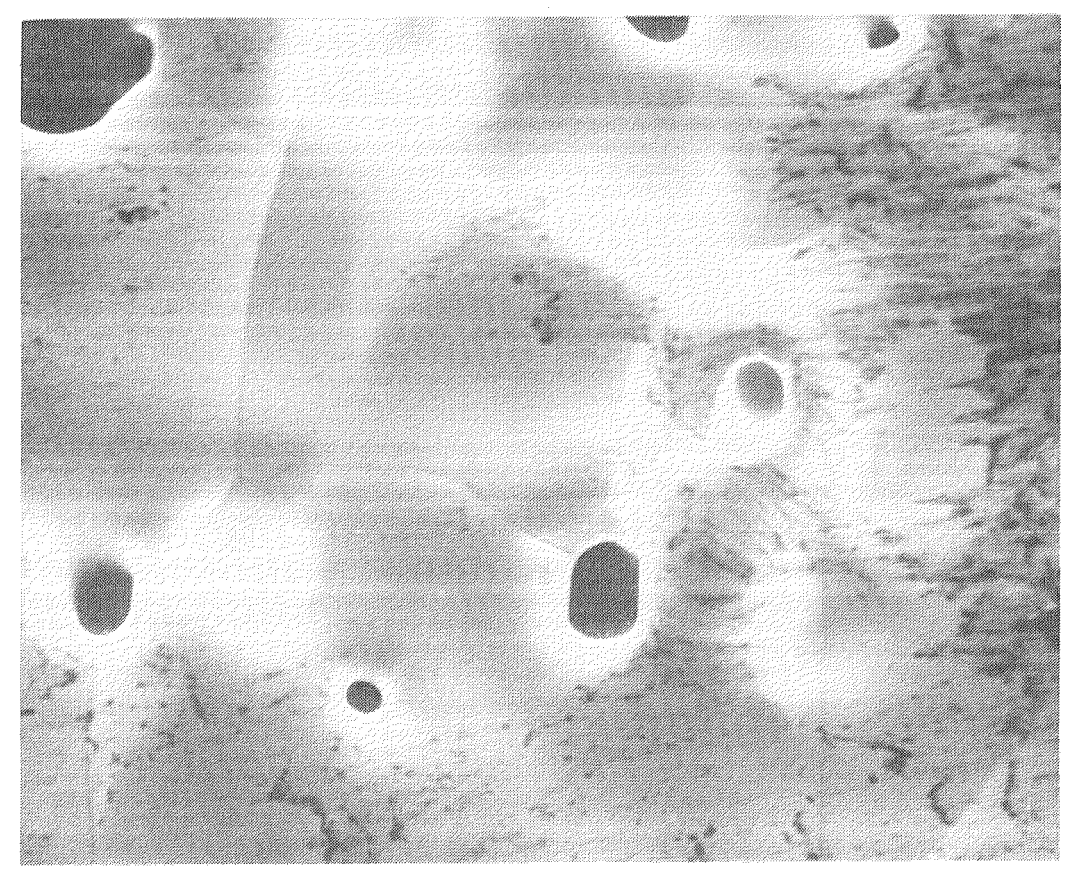

Figure 8. - $\mathrm{Pt} / \mathrm{Y}_{2} \mathrm{O}_{3}$ surface after $1000 \mathrm{hr}$ at $1400{ }^{\circ} \mathrm{C}$ in $\mathrm{NH}_{3}(1000 \mathrm{X})$. 


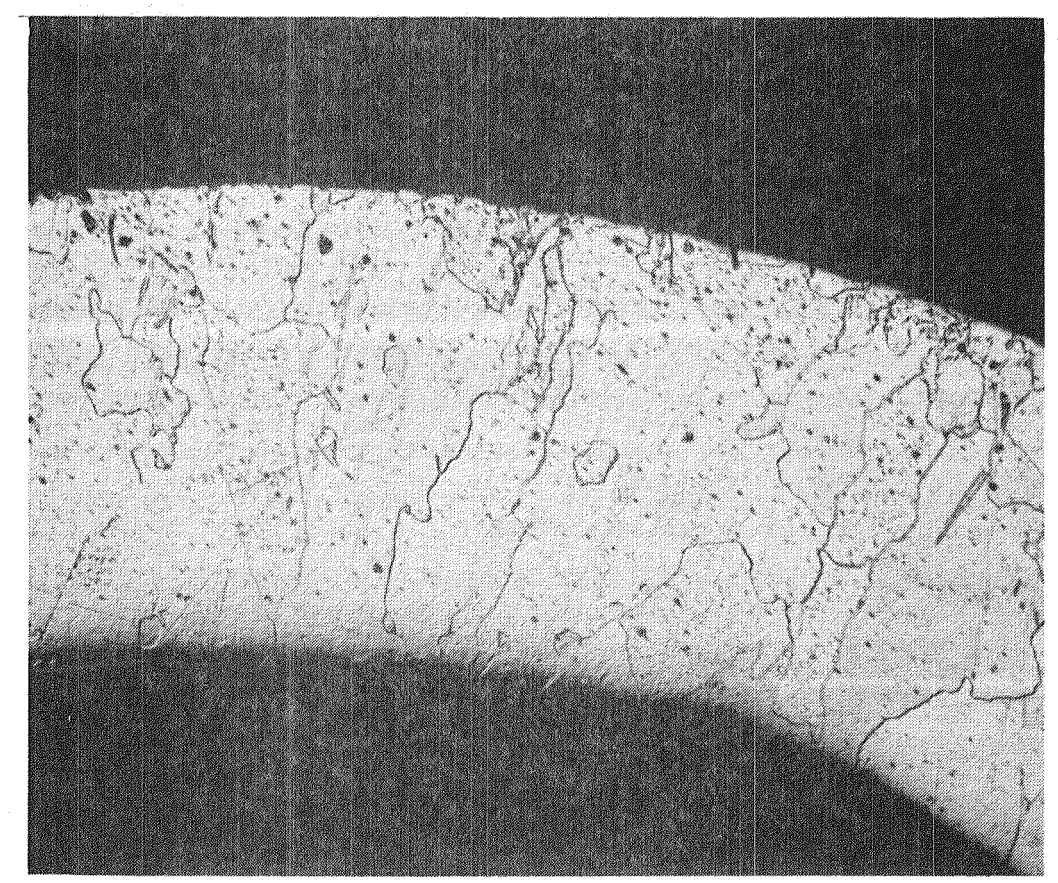

Figure \%- - Pt $/ \mathrm{Y}_{2} \mathrm{O}_{3}$ after anneal at $1000^{\circ} \mathrm{C}$ for $30 \mathrm{~min}(200 \mathrm{X})$.

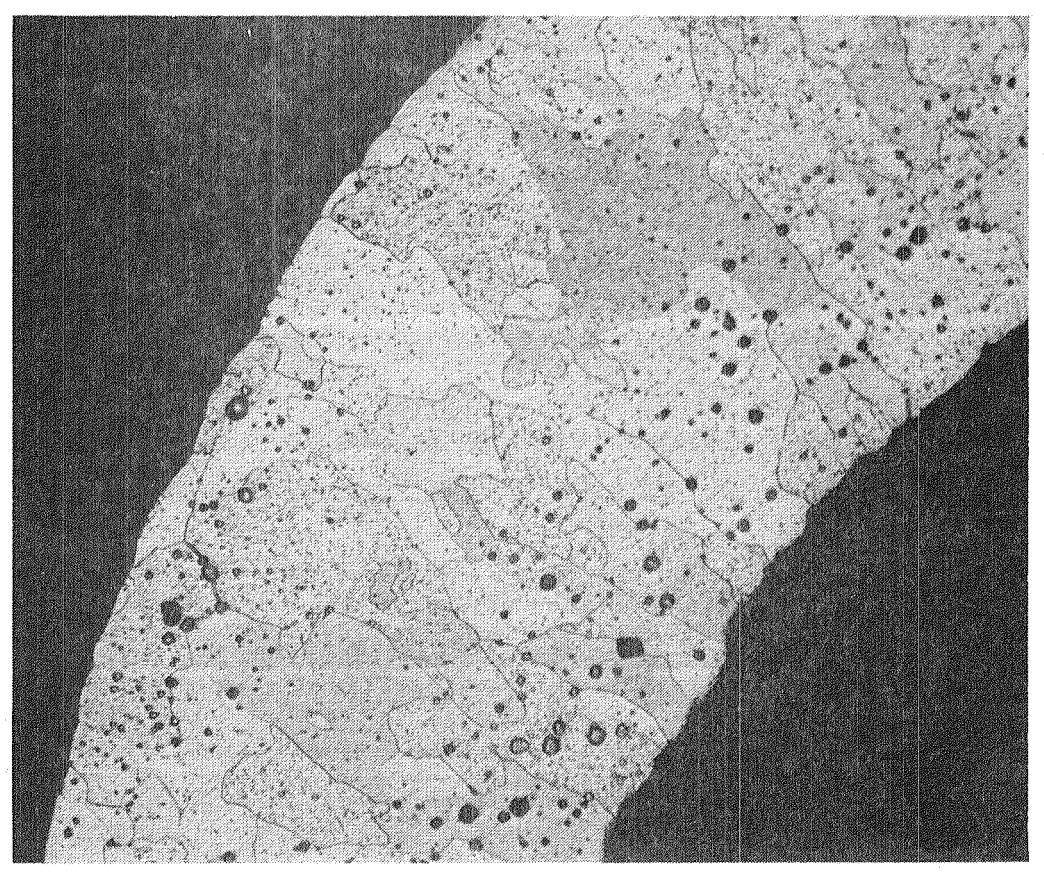

Figure 10. - Cross-section of $\mathrm{Pt} / \mathrm{Y}_{2} \mathrm{O}_{3}$ after $1000 \mathrm{hr}$ at $1400{ }^{\circ} \mathrm{C}$ in $\mathrm{CO}_{2}(200 \mathrm{X})$. 


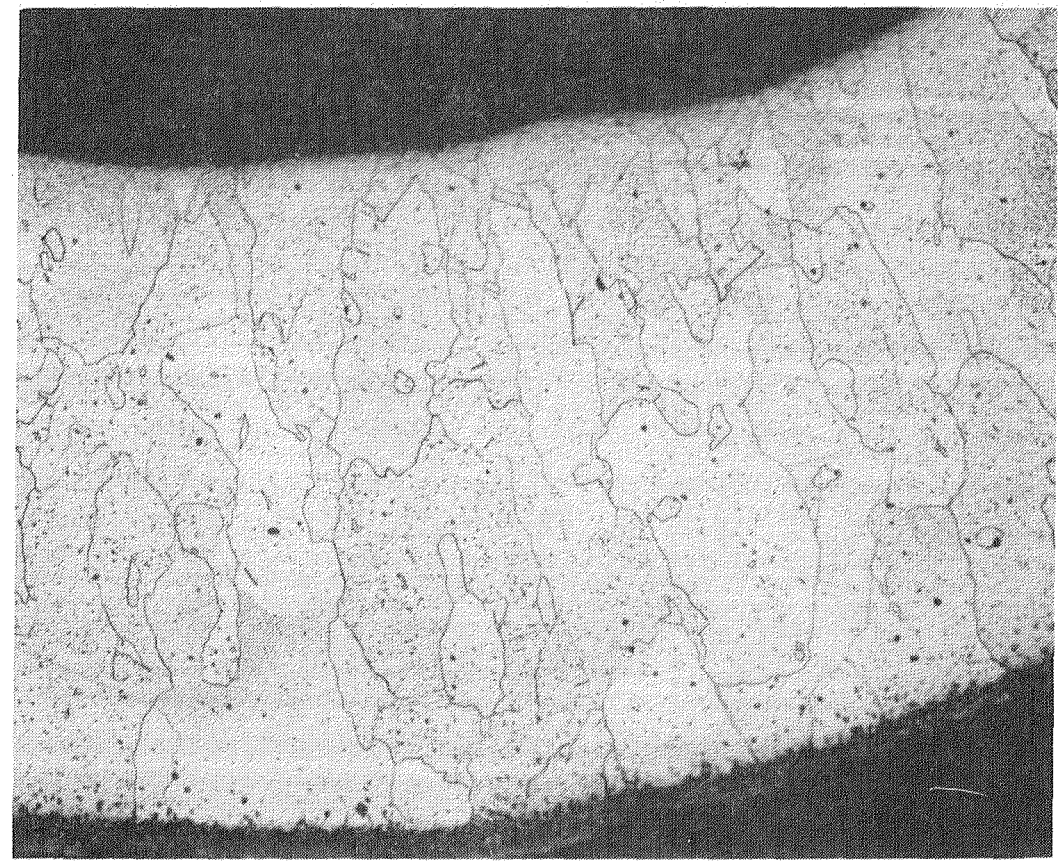

Figure 11. - $\mathrm{Pt} / \mathrm{Y}_{2} \mathrm{O}_{3}$ Cross-section after $1000 \mathrm{hr}$ at $500{ }^{\circ} \mathrm{C}$ in $\mathrm{CH}_{4}(200 \mathrm{X})$.

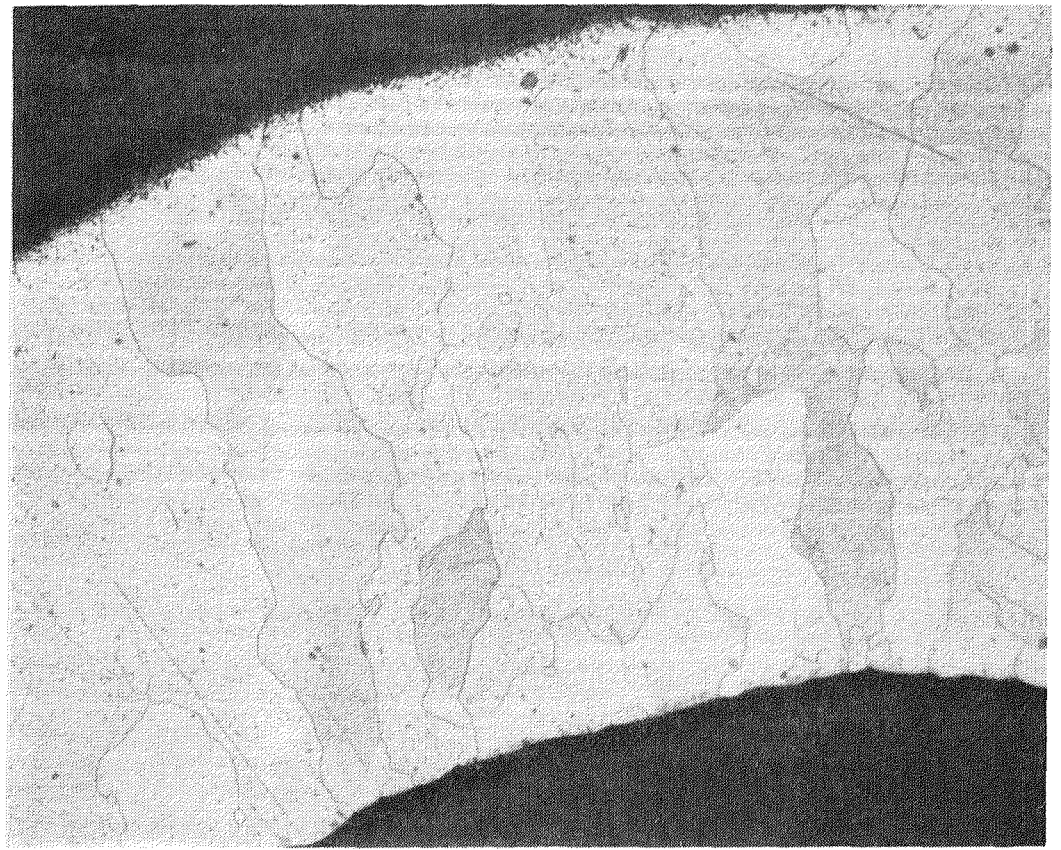

Figure 12. - $\mathrm{Pt} / \mathrm{Y}_{2} \mathrm{O}_{3}$ cross-section after $1000 \mathrm{hr}$ at $1400{ }^{\circ} \mathrm{C}$ in $\mathrm{H}_{2}(200 \mathrm{X})$. 


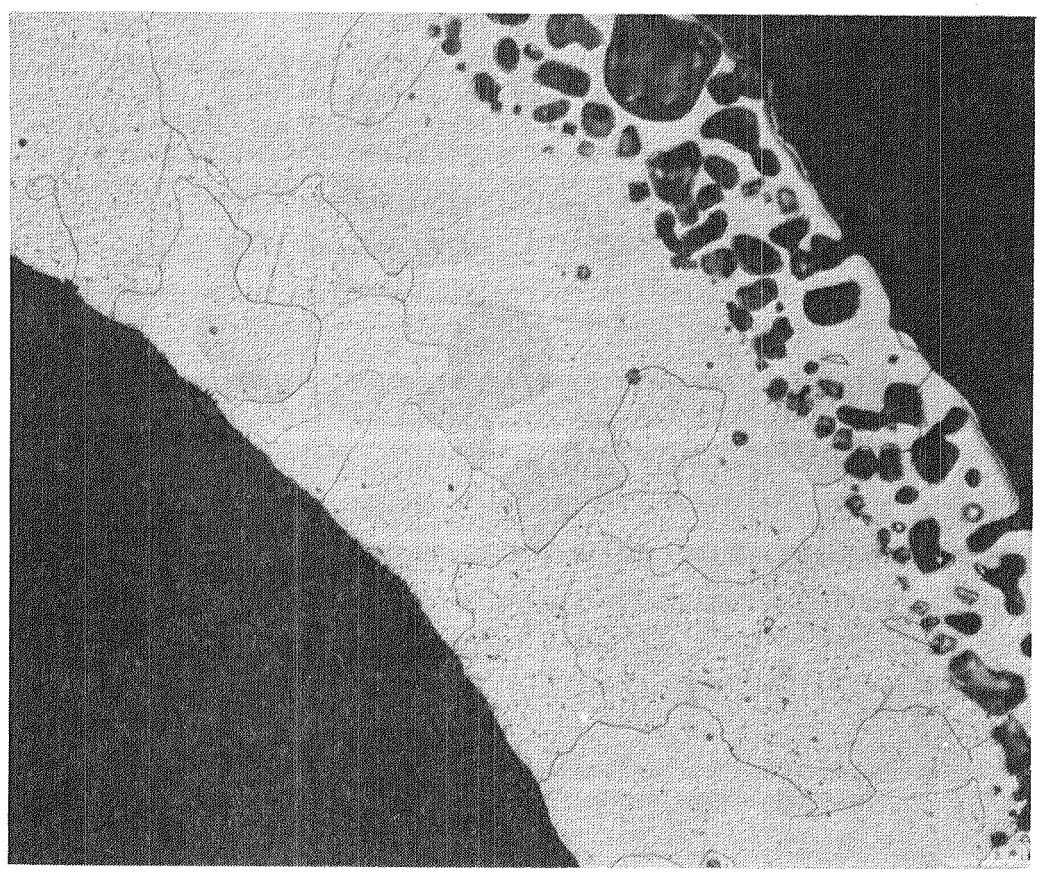

Figure 13. $-\mathrm{Pt}_{2} \mathrm{Y}_{2} \mathrm{O}_{3}$ cross-section after $1000 \mathrm{hr}$ at $1400{ }^{\circ} \mathrm{C}$ in $\mathrm{NH}_{3}(200 \mathrm{X})$. 


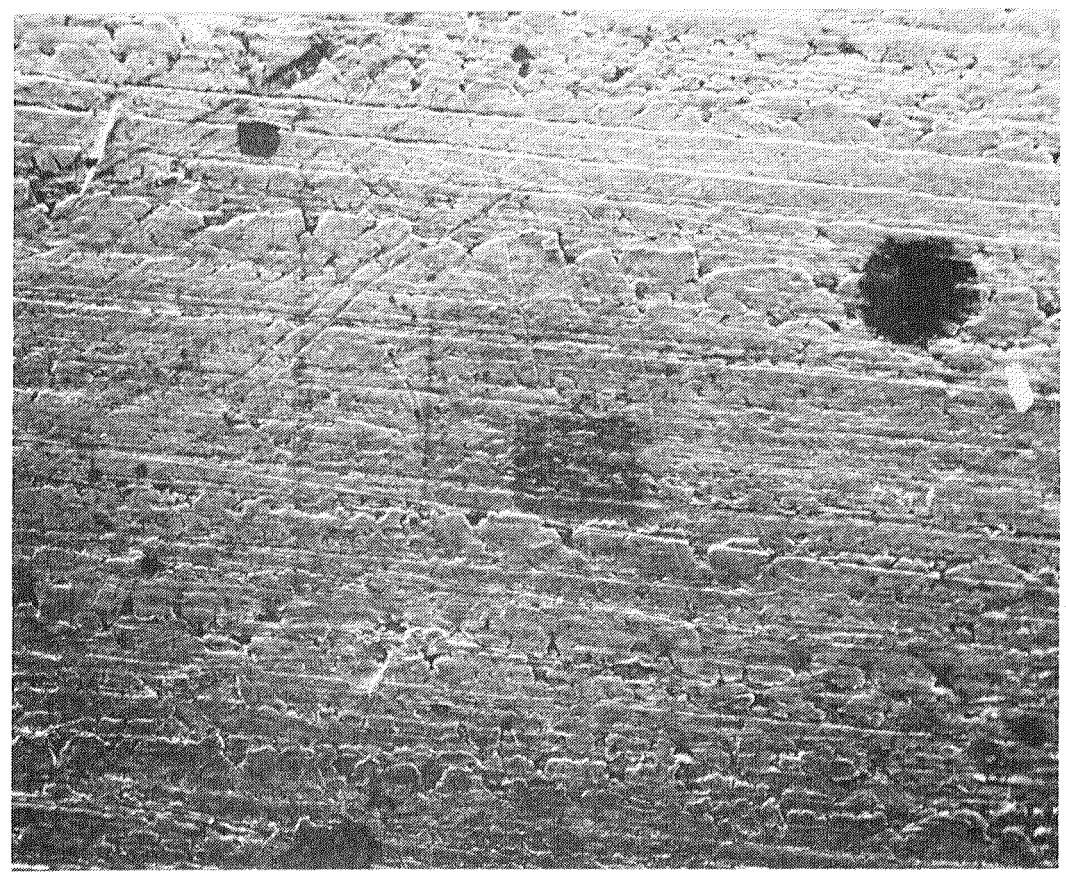

Figure 14. - Platinum-zirconia surface before testing.

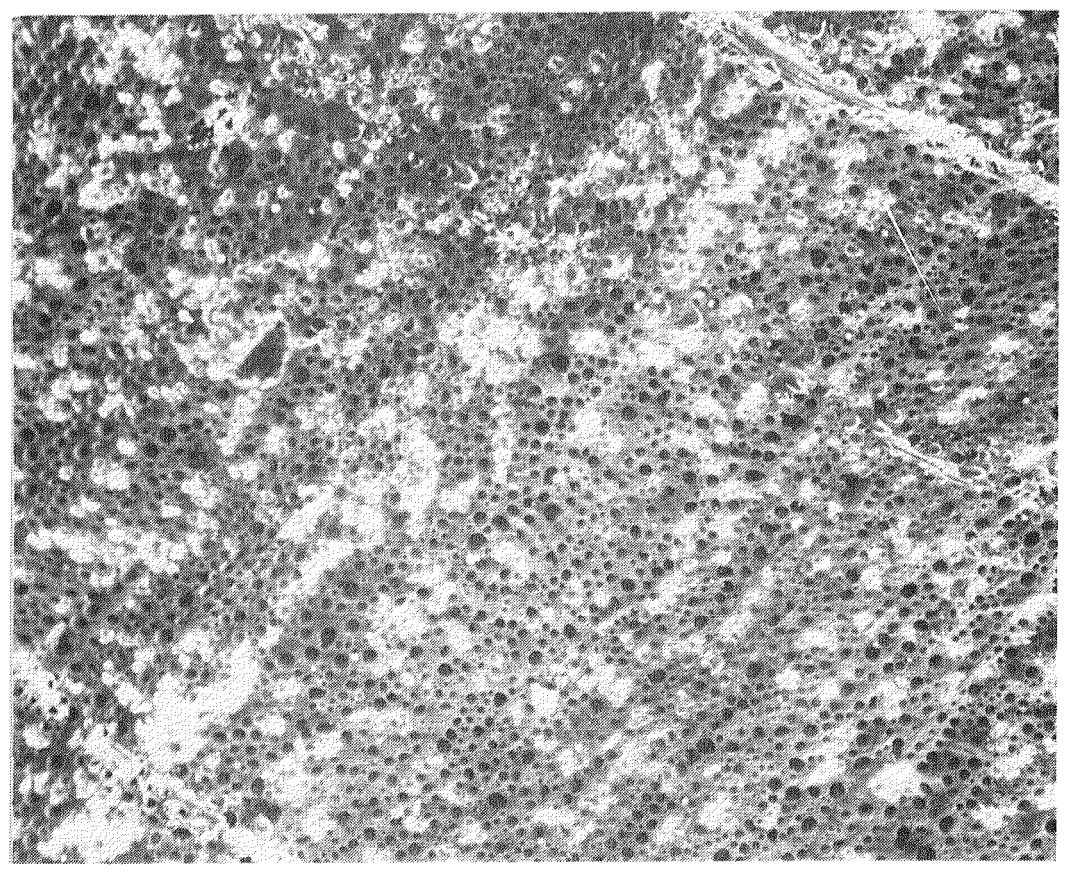

Figure 15. - $\mathrm{Pt} / \mathrm{ZrO}_{2}$ surface after $1000 \mathrm{hr}$ at $1400{ }^{\circ} \mathrm{C}$ in $\mathrm{CO}_{2}(200 \mathrm{X})$. 


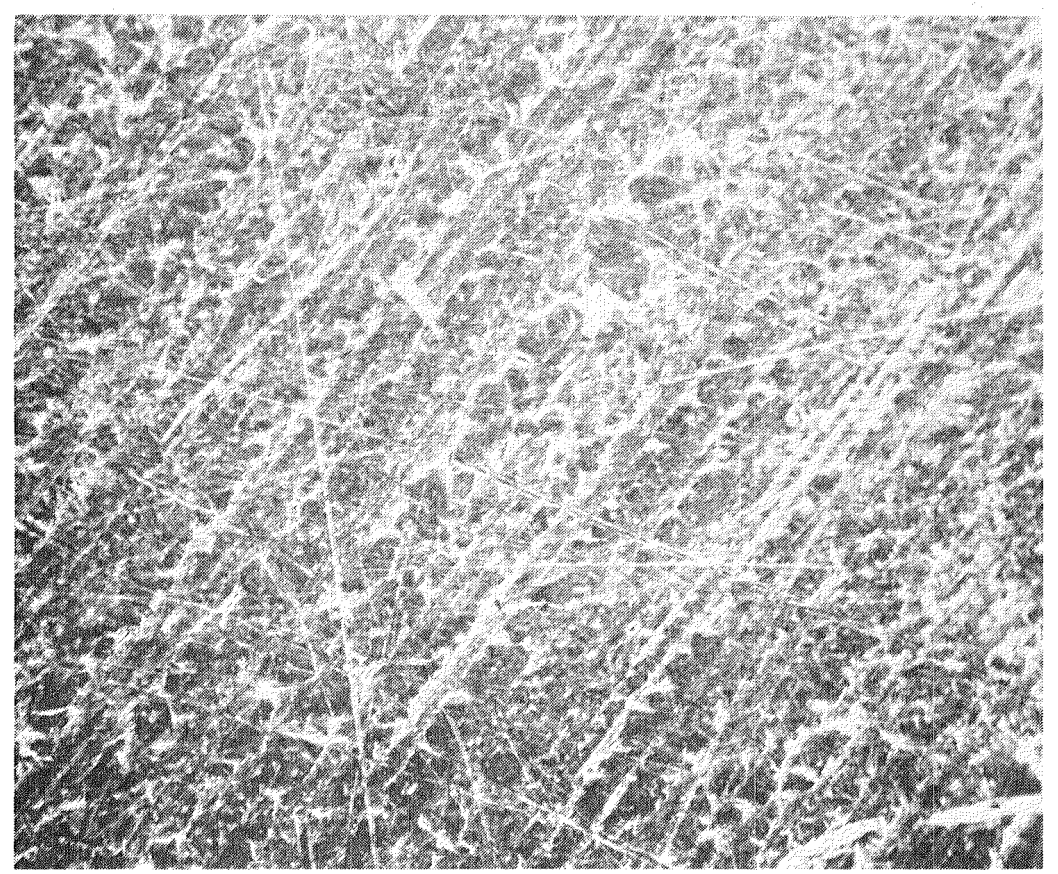

Figure 16. - $\mathrm{Pt} / \mathrm{ZrO}_{2}$ surface after $1000 \mathrm{hr}$ at $500{ }^{\circ} \mathrm{C}_{\text {in } \mathrm{CH}_{4}}$ (200X).

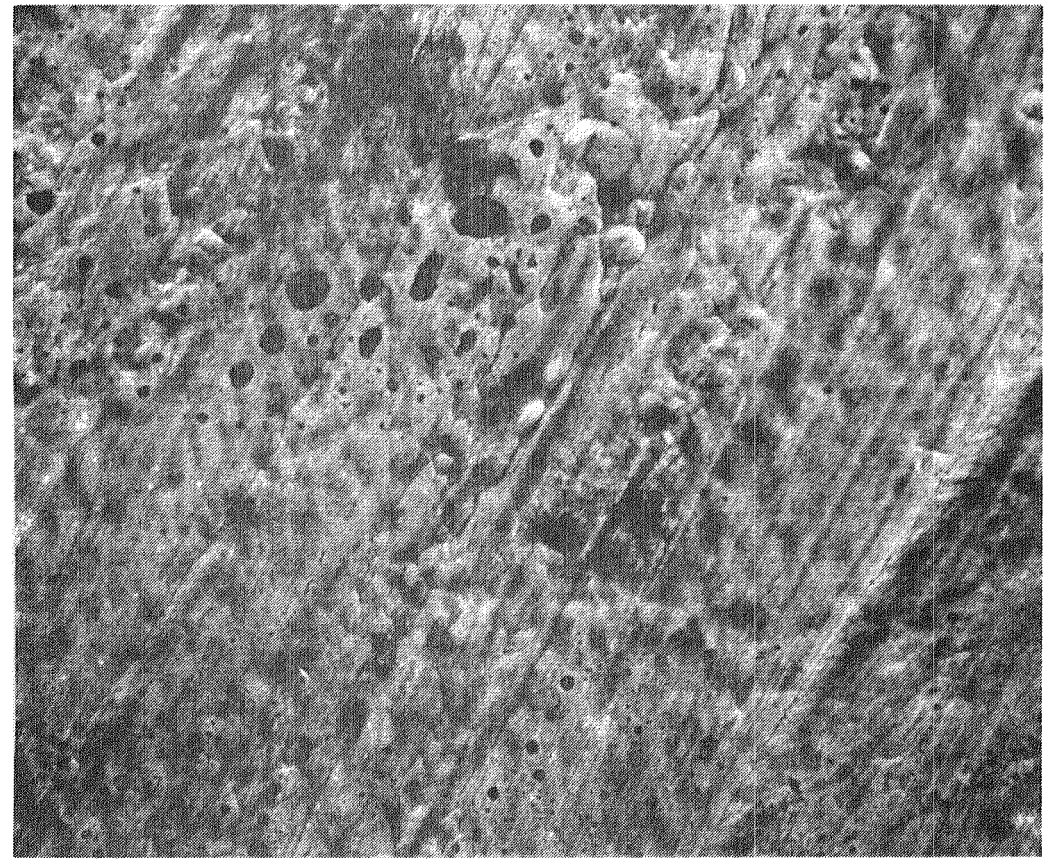

Figure 17. - Pt/ZrO 2 surface after $1000 \mathrm{hr}$ at $1400{ }^{\circ} \mathrm{C}$ in $\mathrm{H}_{2}(200 \mathrm{X})$. 


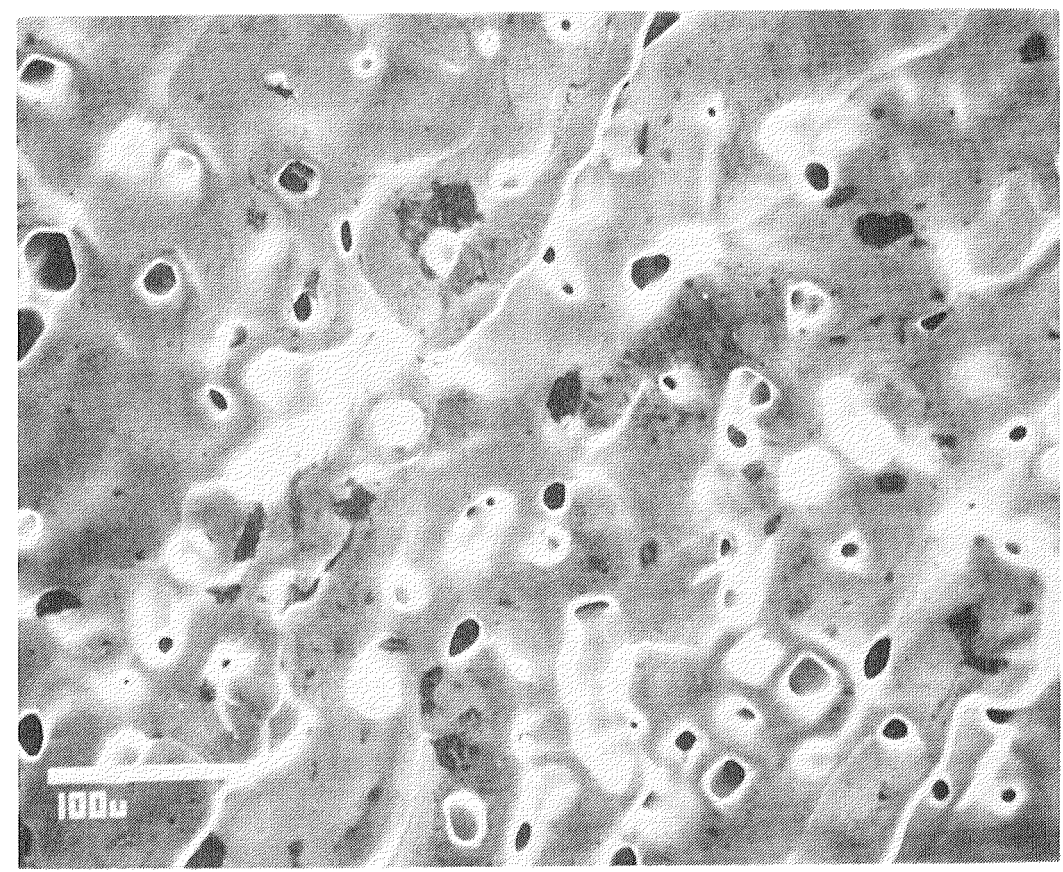

Figure 18. $-\mathrm{Pt} / \mathrm{ZrO}_{2}$ surface after $1000 \mathrm{hr}$ at $1400^{\circ} \mathrm{C}$ in $\mathrm{NH}_{3}$ (200X).

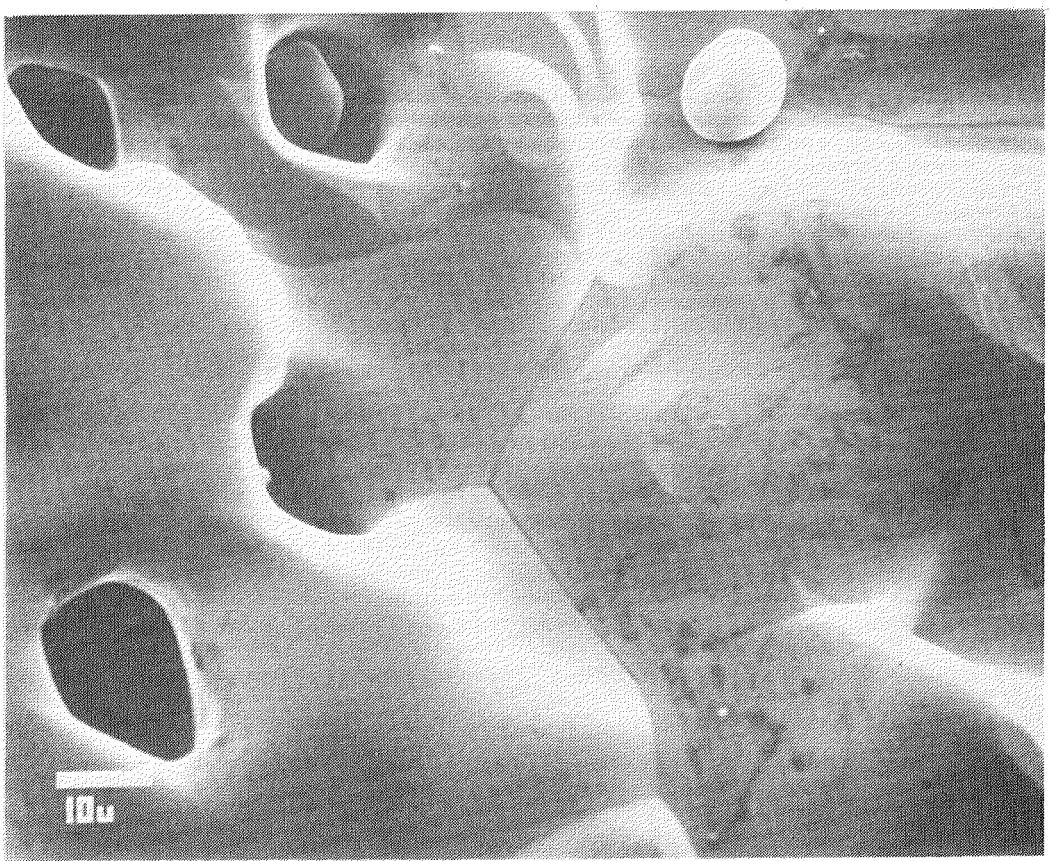

Figure 19. - $\mathrm{Pt} / \mathrm{ZrO} \mathrm{Z}_{2}$ surface after $1000 \mathrm{hr}$ at $1400{ }^{\circ} \mathrm{C}$ in $\mathrm{NH}_{3}(200 \mathrm{X})$. 


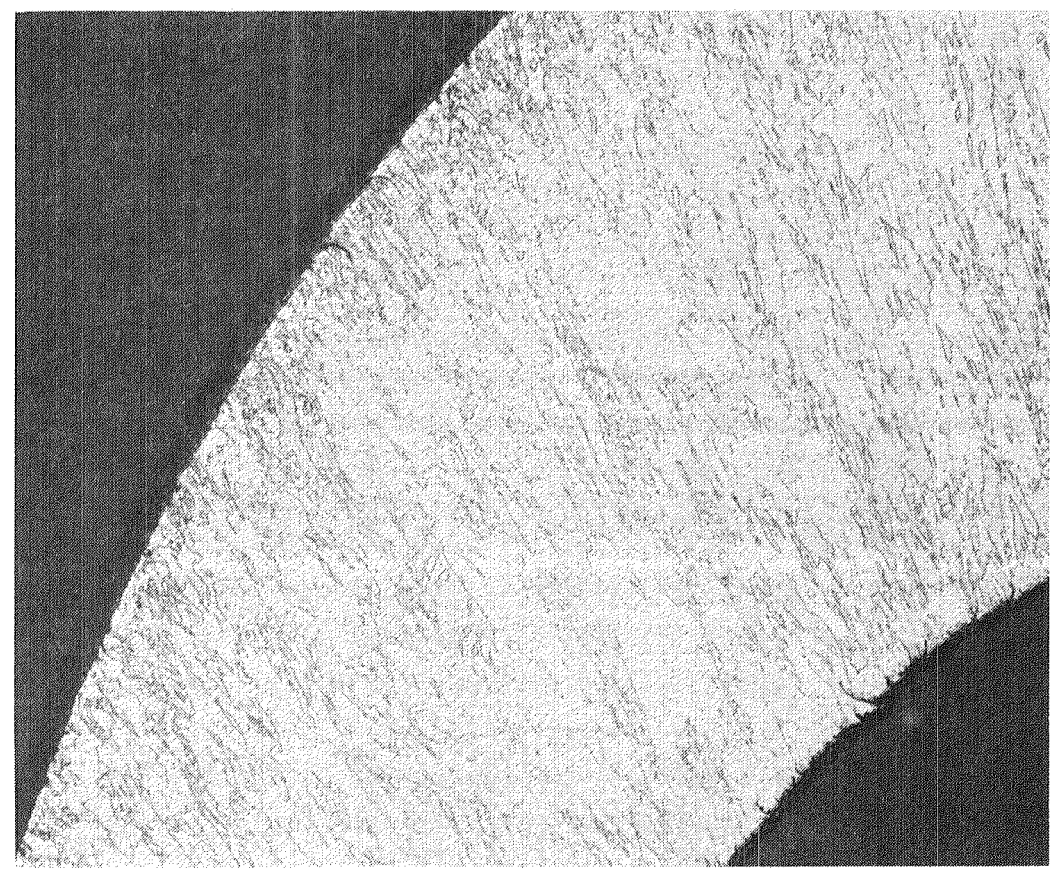

Figure 20. - Pt/ZrO 2 cross-section before testing (200X). 


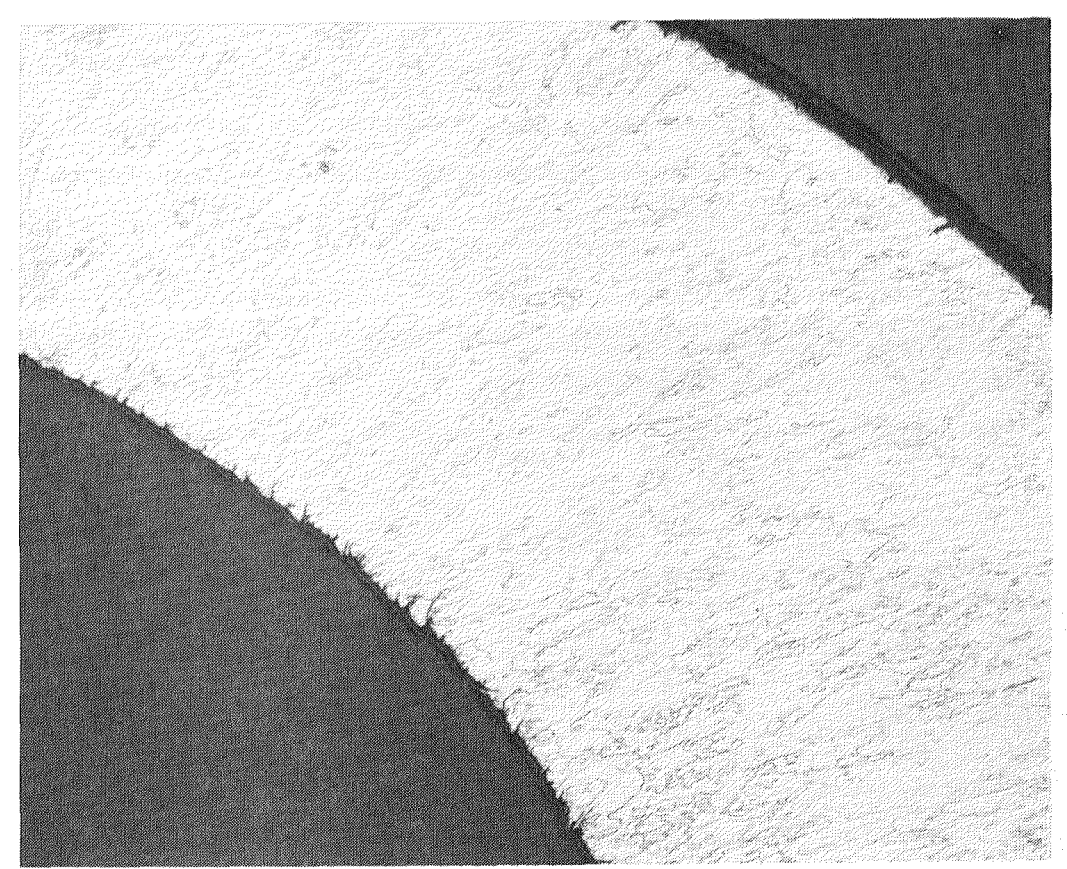

Figure $21_{0}-\mathrm{Pt} / \mathrm{ZrO}_{2}$ cross-section after $1000 \mathrm{hr}$ at $500{ }^{\circ} \mathrm{C}$ in $\mathrm{CH}_{4}(200 \mathrm{X})$.

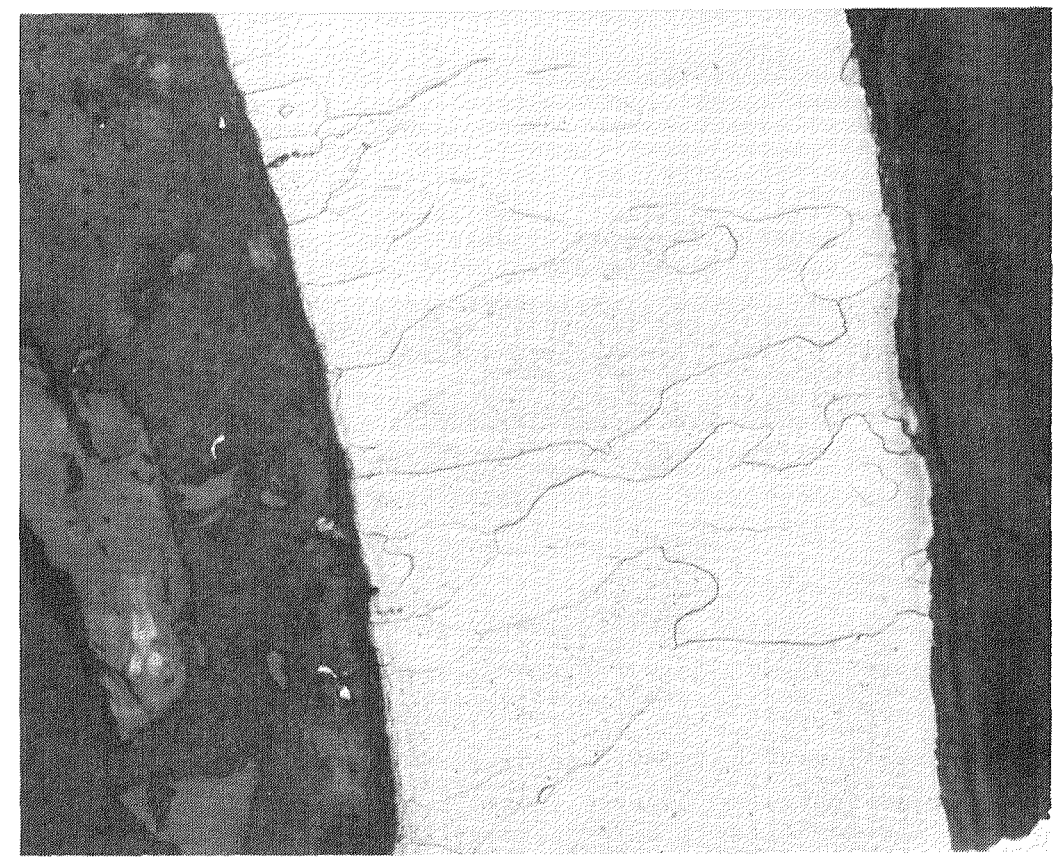

Figure 22. - $\mathrm{Pt} / \mathrm{ZrO}_{2} \mathrm{Cross}^{-}$section after $1000 \mathrm{hr}$ at $1400{ }^{\circ} \mathrm{C}$ in $\mathrm{CO}_{2}(200 \mathrm{X})$. 


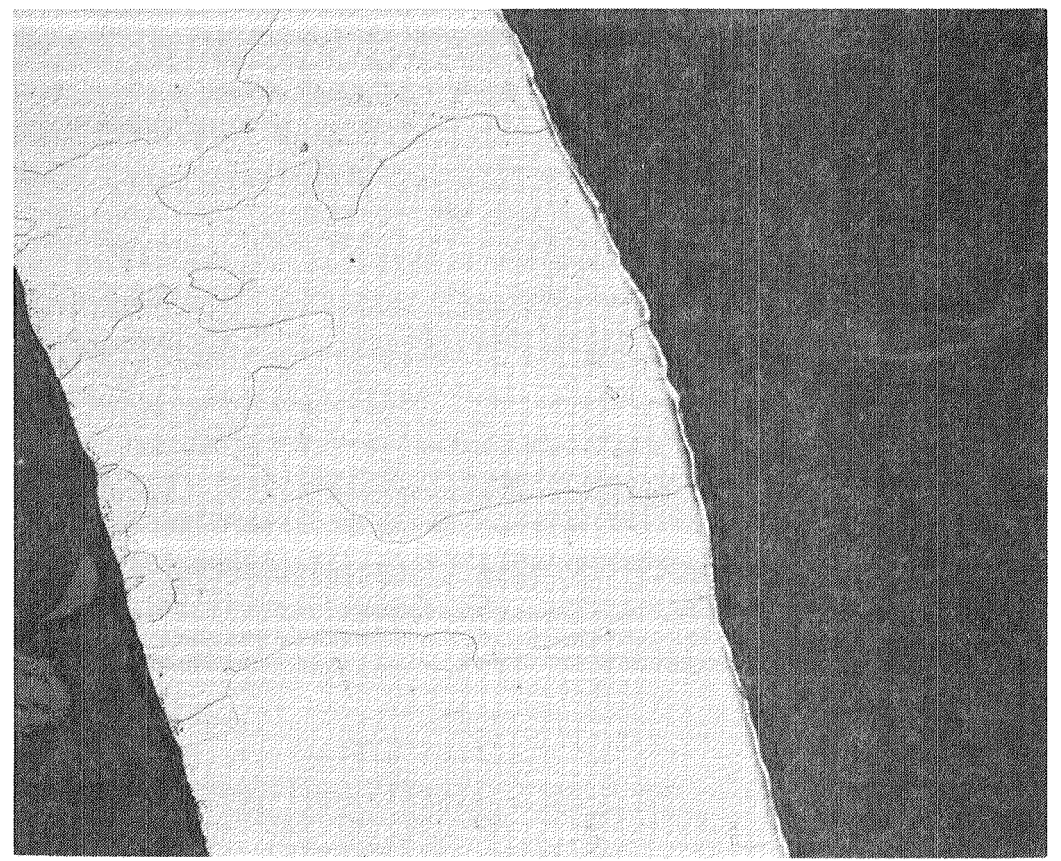

Figure 23. $-\mathrm{Pt} / \mathrm{ZrO} \mathrm{C}_{2}$ cross-section after $1000 \mathrm{hr}$ at $1400{ }^{\circ} \mathrm{C}$ in $\mathrm{H}_{2}(200 \mathrm{X})$.

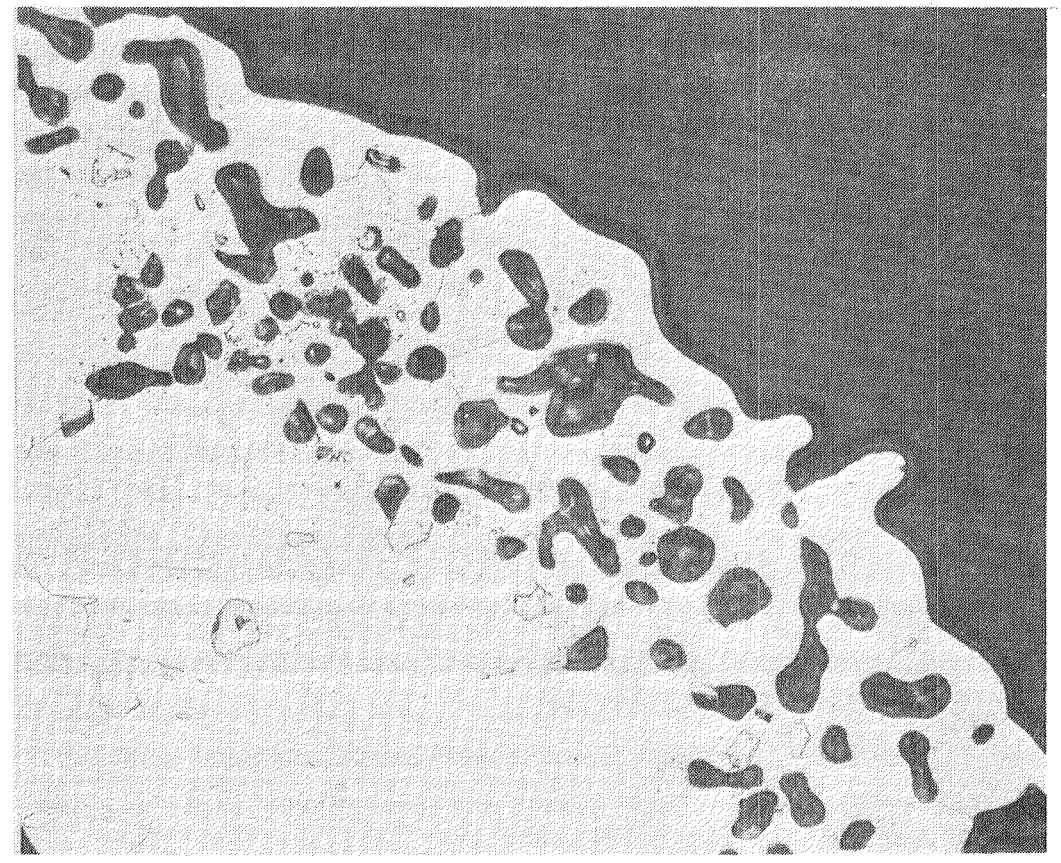

Figure 24. - Pt/ZrO 2 cross-section after $1000 \mathrm{hr}$ at $1400{ }^{\circ} \mathrm{C}$ in $\mathrm{NH}_{3}(200 \mathrm{X})$. 


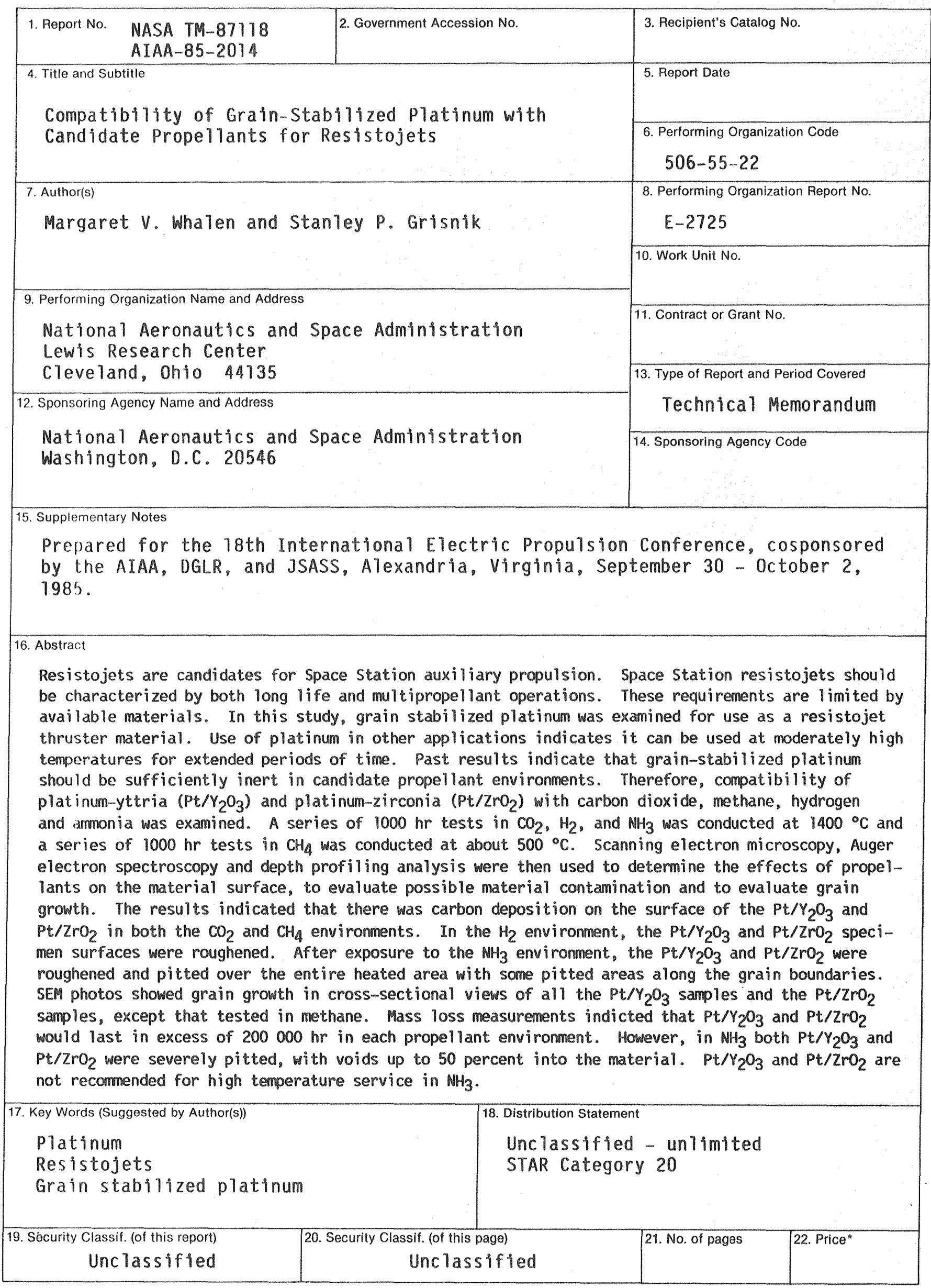

*For sale by the National Technical Information Service, Springfield, Virginia 22161 


\section{End of Document}

